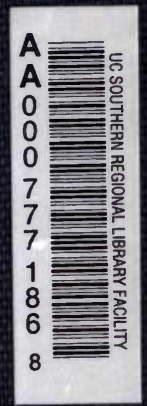




\section{Southern Branch} of the

University of California

\section{Los Angeles}

Form L 1

$$
\begin{aligned}
& \text { QR } \\
& 75 \\
& \text { G91 }
\end{aligned}
$$


This book is DUE on the last date stamped below MAR $4 \quad 1929$

Mar 22 is20

DEC $16 \quad 1930$

DEC 41944

MAY $14 \quad 1931$

AUG 151945

JUL 311931

IDEC 21932

EEB 81954

OCT 31933

MAY $5 \quad 1947$ OCT 151947

WAR 23

10CT 12

हली $26^{\circ}+7^{2 *}$

OCT $\& 5195 \%$

DEC 2.9 inan

430

- MAR 281935 NOV 6

MAR 111940

MAR 161942

OCT 211944

Form L-9-2m-12,'23 


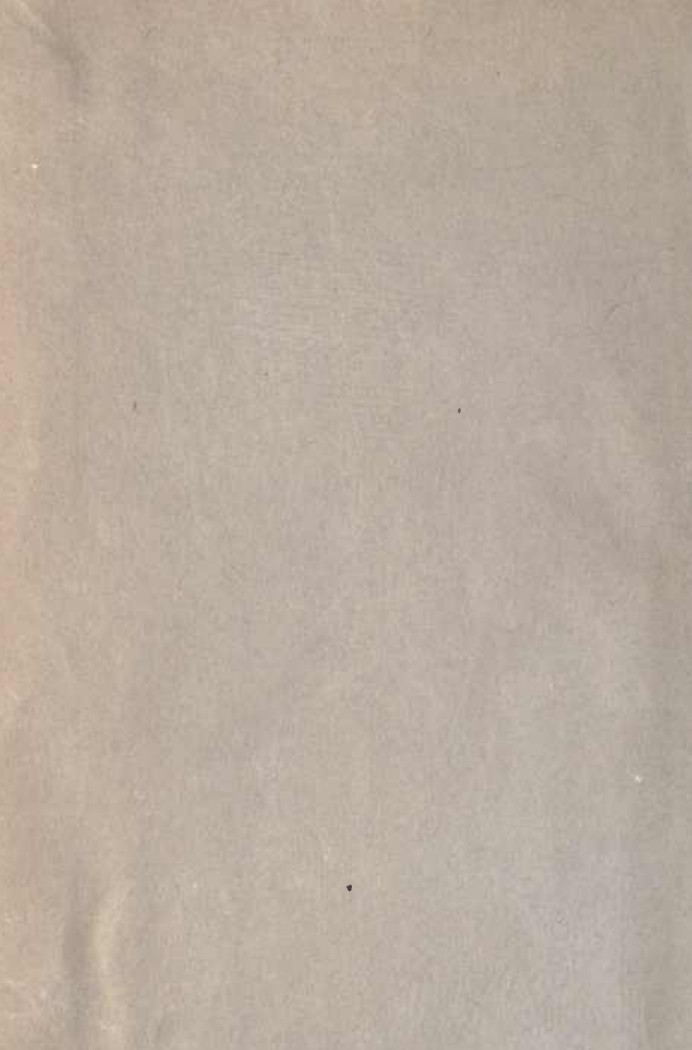






\section{STATE NORMAL SCHOOL,}

Los Angeles. Cal.

A SYNOPSIS

OF THE

BACTERIA AND YEAST FUNGI 



\section{A SYNOPSIS}

OF THE

\section{BACTERIA AND YEAST FUngI}

AND ALLIED SPECIES

(SCHIZOMYCETES AND SACCHAROMYCETES)

\section{By W. B. GROVE, B.A.}

ION. LIBRARIAN OF THE BIRMINGHAM NATURAL HISTORY AND MICROSCOPICAL SOCIETY

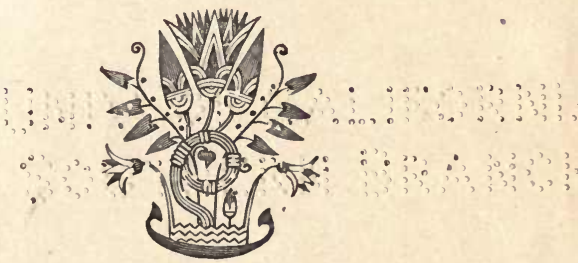

WITH EIGHTY-SEVEN ILLUSTRATIONS

638

进ondon

CHATTO AND WINDUS, PICCADILLY 1884 


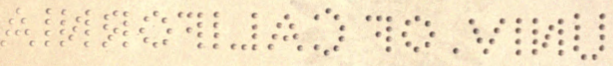

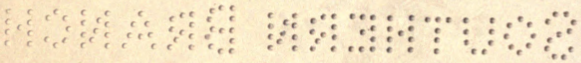




\section{QR7 5 \\ G.91}

\section{PREFACE.}

THE aim of this little work is almost purely morphological; physiological details are only occasionally introduced. The two first chapters are translated, with additions, the more important of which are indicated by square brackets [], from Dr. G. Winter's edition of "Die Pilze," in Rabenhorst's "Kryptogamen-Flora," by kind permission of the author. With a view to increase its usefulness, I have added to the few figures there given a considerable number drawn from various sources, in many cases from the original authorities, and a few of my own. I must acknowledge my indebtedness, for help of various kinds, to Dr. Winter, and also to Dr. John Anthony, of Birmingham, and Mr. James Britten; and, in addition, to the "Summary of Current Researches," in the Fournal of the Royal Microscopical Society, as a guide to the literature of the subject.

W. B. GROVE.

BIRMINGHAM, May ist, I 884 . 



\section{CONTENTS.}

CHAPTER

I. SCHIZOMYCETES

II. SaCcharomycetes

III. Classification

IV. Protean and Little-known Sprcies

Appendix A. On the Unit of Microscopical MeasureMENT

B. On the Staining of “Bacillus Tuberculosis" 103

, C. Diseases produced by the Schizomycetes ios
AGE

I

INDEX $\ldots$

... 107 



\section{SYNOPSIS OF THE BACTERIA AND YEAST FUNGI.}

CHAPTER I.

SCHIZOMYCETES.

The Schizomycetes, or "splitting-fungz (Spaltpilze), are unicellular plants, which multiply by repeated subdivision in one, two, or three dimensions of space, and also frequently reproduce themselves by spores, which are formed endogenously.

They live, either isolated or combined in various ways, in fluids and in living or dead organisms, in which they produce decompositions and fermentations, but never alcoholic fermentation.

The Schizomycetes are one of the most difficult and least-known classes of Fungi. In the first place, it is doubtful whether they are to be reckoned among the Fungi or not. Cohn unites them with the Phycochromaceæ, which are usually considered to be Algæ, and includes both groups under the name of Schizophytæ. I cannot agree to this union. With respect to morphological relations, indeed, the Schizomycetes are in many ways exceedingly like the Phycochromaceæ; but their physiological relations are quite 


\section{Synopsis of the Bacteria and Yeast Fungi.}

different. The latter live, like all Algæ, in pure water, which contains comparatively little organic matter; or they are found on dripping rocks, on damp ground, etc.; they produce no striking decompositions in the water which they inhabit, and they soon perish in a putrefying liquid.

It is quite otherwise with the Schizomycetes, which, on account of their want of chlorophyll, are reduced to live on ready-organized substances, as are Fungi generally. The Schizomycetes, therefore, produce in their substratum, or in the fluid which they inhabit, very considerable and striking decompositions. They perish in pure water, containing no decomposable substance. They grow, therefore, exclusively in organic liquids, or in water or on damp spots where there is an abundance of organized matter.

Though we are thus certainly justified in separating the Schizomycetes from the Phycochromacex, i.e. from the Algæ, it still remains to be decided how they are to be limited from the animal kingdom. In fact, the Schizomycetes stand at that stage in the evolution of organic beings at which it is not possible to draw a sharp line of demarcation between the two kingdoms. Their kinship with the mouthless monads has often been remarked, and one is inclined more and more to unite the latter with them. I restrict myself to indicating this point, while provisionally I still exclude these forms from the Schizomycetes; they require much further and exhaustive study. Unfortunately this is true in a high degree of the Schizomycetes themselves; both the morphological and systematic as well as the physiological relations of this group of Fungi are still very insufficiently investigated. Doubts and uncertainties of many kinds have still to be removed.

Among the forms which are included among the Schizomycetes in the following pages, are many which have often 
hitherto been described as Algæ, but which, on account of their want of chlorophyll, and their decomposing power, must be reckoned among the Fungi.

The Fungi here treated of are the smallest with which we are acquainted. The form of the cells is various-round, ovate, elliptic, cylindrical, etc. They live isolated, singly or in larger or smaller swarms, or in many cases united in pairs, or many together in threads or groups. Many forms are always motionless; others, on the contrary, show a more or less active spontaneous movement, which is frequently effected by flagella. In this case the cells swim about swiftly, rotating round their longitudinal axis. In other cases the movement is an oscillating one or the threads alternately bend and straighten themselves, etc.

But even the motile forms for the most part possess certain stages in which they are motionless. In this case, usually, countless aggregated cells excrete a gelatinous or slimy mass, which either presents a sharply bounded, variously shaped contour-round, sac-like, ragged, or even branching - or else is without definite outline Such a gelatinous colony is designated a zoogloea; it is a restingstage, which often precedes the formation of spores, and often also occurs in typically motionless forms.

The formation of spores is known in many Schizomycetes; it has been most accurately observed in Bacillus subtilis, in which I will briefly describe it. The cells of the genus Bacillus are short cylindrical rods, which increase by repeated transverse division, and have a flagellum at each end, by the active vibration of which the rod is moved. In spore-formation the greater part of the contents collects at one point of the rod, which often projects as a swelling, and is sharply marked off from the other empty part of the cell. Afterwards this strongly refringent, dark-looking body (the spore) 


\section{Synopsis of the Bacteria and Yeast Fungi.}

disarticulates itself from the barren part of the cell, which then perishes, and the mature spore remains behind. These spores possess the power of enduring adverse influences of various kinds without injury to their vitality. They can remain a long time in the ground, and then years after proceed with their development; they can also germinate at once. At germination the spore first loses its brilliancy, and swells up somewhat; then the membrane of the spore bursts in the middle. The inner part of the spore projects through the opening, and grows to a new rod, the base of which is sheathed by the split membrane, which is often not thrown off for some time.

When we attempt to define the genera and species of the Schizomycetes, as we are wont to do with other plants, we encounter great difficulties, which must first be shortly mentioned. The question is-What, in these Fungi, is to be considered a genus and a species?

That there exist a number of different genera, i.e. groups of distinct forms, in the Schizomycetes, is almost universally admitted. But there are two opposed views concerning the limitation of these genera. Naegeli recognises only a few very variable groups of forms, while Cohn establishes a whole series of genera, which he sharply distinguishes, and which he divides into numerous species. To me it seems very probable that several really distinct and constant genera exist, e.g. Micrococcus (in an extended sense), Bacillus, Spirillum, and Sarcina; while others of Cohn's genera are only stages of development. I should decidedly allow that the number of species is far smaller than one would judge from Cohn's classification. For many of these species are very probably only forms which have been differentiated by the influence of various external agencies, and have become more or less constant. 
It is in part quite impossible, especially in the genera Micrococcus and Bacterium, to indicate morphological distinctions between the species. We are in these cases confined exclusively to physiological distinctions; we employ differences in chemical action for the limitation of species. The Schizomycetes, as has been already stated, excite peculiar decompositions in their substratum ; they transform complicated chemical combinations into simpler ones. This chemical action consists ( $\mathrm{I}$ ) in the production and excretion of colouring matters ; (2) in the exciting of various fermentations; and (3) in the decomposition of the humours of animal and human bodies, whereby diseases arise. We distinguish, therefore, (I) chromogenous, (2) zymogenous, and (3) pathogenous species respectively.

But especially in relation to those forms which belong to the two last subdivisions does the greatest uncertainty reign. Nay, in regard to the pathogenous Schizomycetes such untrustworthy, even foolish, assertions and so-called observations have been published, that only the greatest foresight can guard against errors.*

There is left, therefore, especially for the systematist, nothing but to accept Cohn's conscientious researches, provisionally to adopt his classification and nomenclature as the only one which is founded upon botanical principles, and to add to it only what has been discovered by trustworthy investigations. The nonsense which Hallier and Co. have tried to introduce into the science naturally remains unregarded.

* This arises chiefly from the fact that many medical men, who have tried to investigate these things, have been totally unskilled in the use of the microscope, at any rate with high powers, and have often also been untrained in the methods of observation. An eminent physician of the United States, Dr. Schmidt, solemnly asserted that the Bacillus tuberculosis of Koch was only a fat-crystal! - TR. 


\section{Synopsis of the Bacteria and Yeast Fungi.}

\section{KEY TO THE GENERA.}

I. Cells round or ovate

Cells cylindrical

Cells lanceolate, flat, spirally twisted

2. Cells isolated or united in chains or formless gelatinous masses

... $\quad$...
spirally twisted
in chains

$\begin{array}{rrrr}\ldots & \ldots & \ldots & 2 \\ \ldots & \ldots & \ldots & 5 \\ \ldots & \ldots & \text { Spiromonas }\end{array}$

Cells united in considerablenumbersin colonies of definite outline 3

3. Colonies hollow, with a simple peripheral cell-layer... Cohniq Colonies solid, with cells throughout their substance

4. Cells united in a small but definite number in regular

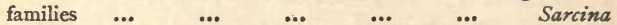

Cells united in a large and indefinite number in irregular

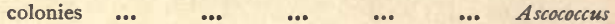

[Cells in chains, each chain surrounded by a gelatinous

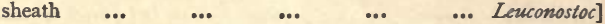

5. Cells shortly cylindrical, single, or loosely combined in twos or a few together $\quad \ldots \quad \quad \ldots \quad \quad \ldots \quad \quad \ldots \quad$ Bacterium

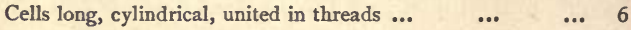

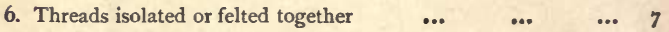
Threads enclosed in roundish gelatinous masses ... Myconostoc

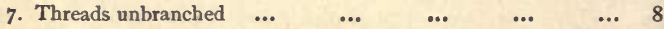
Threads with evident branching ... $\quad$... $\quad \ldots$ Cladothrix:

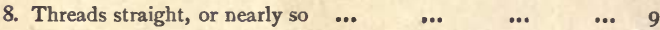
Threads spirally wound or bent $\ldots \quad$... $\quad \ldots \quad$... $\quad$ II

9. Threads conspicuously articulated, rather short ... Bacillus Threads mostly not conspicuously articulated, long _.. 10

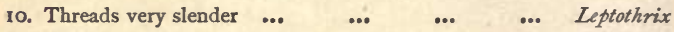

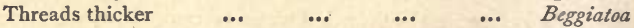

11. Threads short, with few spirals, or simply bent, rigid Spirillum Threads longer, with numerous spirals, flexile ... Spirochata

I. MICROCOCCUS, Cohn ("Beiträge zur Biologie," i. p. 15 r.)

Cells colourless or of a pale tint, round or oval-elliptic, motionless, dividing in one direction only. The daughtercells either soon separate from one another, or remain united in a chain of two or more, or form a zooglœa. Formation of the spores not certainly known. 
What I have said above of the distinctions of the species is especially true of this genus. The accepted species of Micrococcus show very little or no difference in form and size, and there remains only chemical action as a means of separating the species, which is therefore treated somewhat fully.

\section{A.-Chromogenous Species.}

I. M. prodigiosus, Cohn (l.c., p. 153). Monas prodigiosa, Ehrenberg. Palmella prodigiosa, Mont.; Cooke, "British Freshwater Algæ," p. 12. Zoogalactina imetropha, Sette. Bacteridium prodigiosum, Schröter.

Cells round or oval, colourless, about ${ }^{-1}{ }^{-1} \mu^{*}$ in diameter; forming at first rose-red, then blood-red, at last pallid gelatinous masses. (Fig. I.)

On nitrogenous substances, e.g. on boiled potatoes, meat, wheat-bread, white of egg, starchpaste, etc.

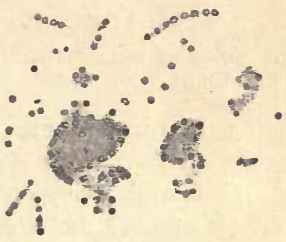

Fig. 1.-Micrococcus prodigiosus, Cohn, $X 1200$ (from nature).

$M$. prodigiosus is that organism which produces the long-known peculiar appearance, formerly designated " blood-rain," on bread, on the "host," etc. It forms at first little rose-red points and heaps, which by degrees increase to rounded bright-red spots, and afterwards become confluent into widespread, even dripping, blood-red patches. These consist of a red-tinted mucous mass, in which thousands of millions of Micrococcus cells are embedded. These cells are themselves colourless, but they secrete the red colouring matter in the mucus. This colouring matter is very similar to fuchsin in its physical and chemical relations. It is not soluble in water, but completely so in alcohol; the solution, evaporated and again dissolved, is orangered ; the colour is changed by acids into a bright carmine, by alkalies

* I $\mu$ (pronounced $m u$ ) $=\cdot 0 \mathrm{OI} \mathrm{mm} .={ }_{25100}$ of an inch, nearly. 
into yellow. In the spectroscope it shows, among others, a characteristic broad absorption band in the green.

Palmella mirifica, Rabenhorst, can scarcely be anything different. (See Fournal of the Royal Microscopical Socicty, 1882, p. 655.)

2. M. luteus, Cohn (l.c., p. 153).

Bacteridium luteum, Schröter.

Cells elliptic, somewhat larger than in $M$. prodigiosus, with highly refractive cell-contents ; forming, on a solid substratum, clear yellow drops, which at first are as large as a poppy-seed, and afterwards as a half-peppercorn; at last drying up to flat shield-shaped umbilicate discs. On nutrient fluids this species forms a thick yellow skin, which becomes plaited when luxuriantly developed.

On boiled potatoes, etc.

Colouring matter insoluble in water, unchanged by sulphuric acid and alkalies.

\section{M. aurantiacus, Cohn (l.c., p. I54).}

Bacteridium aurantiacum, Schröter.

Cells oval, about $I \cdot 5 \mu$ long; on a solid substratum in orange-coloured drops and spots, which at last coalesce into equal-sized patches. On nutrient solutions it forms a golden-yellow skin.

On boiled potatoes and eggs.

Colouring matter soluble in water.

4. M. fulvus, Cohn (l.c., p. I8r).

Cells round, about $\mathrm{r}_{5} 5 \mu$ in diameter; at first forming rusty conical tolerably firm drops of $\frac{1}{2} \mathrm{~mm}$. in thickness, which increase and finally produce extended gelatinous masses. (Fig. 2.)

On horse-dung.

Fig. 2.-Micrococcus fulvus (after Cohn).
5. M. chlorinus, Cohn (l.c., p. r 55).

Cells round (?), forming yellowish-green or 
sap-green mucous masses, or in fluids sap-green layers, which by degrees colour the whole fluid yellow-green.

On boiled eggs.

The colouring matter is soluble in water; it is not reddened by acids.

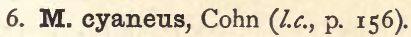

Bacteridium cyaneum, Schröter.

Cells elliptic; producing on slices of potato an intense blue, which penetrates also into the interior, or even to the opposite side of the slice. In fluids it forms a zooglœa, which at first is colourless, then bluish-green, and at last intense blue.

On boiled potatoes.

The colouring matter is soluble in water; the solution is at first verdigris-green, but afterwards usually becomes clear blue. It is coloured intense carmine by acids, and then by alkalies blue or sap-green respectively. In the spectroscope it shows no absorption bands, but only a darkening of the less refractive half.

7. M. violaceus, Cohn (l.c., p. 157). Bacteridium violaceum, Schröter.

Cells elliptic, larger than those of $M$. prodigiosus; occurring in bright violet-coloured gelatinous drops, which unite to form larger spots, reaching $6 \mathrm{~mm}$. in diameter.

On boiled potatoes.

\section{B.-Zymogenous Species.}

8. M. ureæ, Cohn (l.c., p. $\left.15^{8}\right)$.

Cells round or oval, $x^{*} 5^{-2} \mu$ in diameter ; isolated or concatenate or forming a zoogloa on the surface of the fluid. (Fig. 4b.)

In urine.

$M$. urea is the ferment of ammonia fermentation. If fresh urine is allowed to stand exposed at a sufficient temperature $\left(30^{\circ} \mathrm{C}\right.$.), it loses its 


\section{IO}

Synopsis of the Bacteria and Yeast Fungi.

acid reaction after a few days, becomes neutral, and finally alkaline, while the phenomena of fermentation are observed. The urea disappears and is changed into carbonate of ammonia, while at the same time alkaline urates and phosphate of ammonia and magnesia are eliminated. This decomposition takes place only when the Micrococcus is developed in the fluid.

9. M. Crepusculum (Ehrenberg), Cohn (l.c., p. 160). Monas Crepusculum, Ehrenberg.

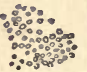

Fig. 3.-Micrococcus Crepusculum (after Ehrenberg).
Cells round or shortly oval, very small, scarcely $2 \mu$ in diameter; isolated or forming a zooglœa. (Fig. 3.)

In and on various infusions and putrefying fluids.

The common form of Micrococcus, which appears in all sorts of decaying substances and in infusions, in company with Bacterium Termo.

ro. M. candidus, Cohn (l.c., p. 160).

On boiled potato-slices, forming snow-white points and spots.

[I I. M. amylivorus, Burrill (American Naturalist, xvii., I883, p. 319).

Cells oval, single or united in pairs, rarely in fours, never in elongated chains, embedded in an abundant mucilage which is very soluble in water, $\mathrm{I}-\mathrm{I} \cdot 4 \mu$ long, $7 \mu$ broad; width of a pair $2 \mu$, of four united about $3 \mu$; movements oscillatory.

In the tissues of plants, causing the so-called "fire-blight" of the pear tree, and similar phenomena in other plants.

Through the action of this organism, the stored starch is destroyed by fermentation, and carbonic acid, butyric acid, and hydrogen are given off. It may be cultivated in pure starch, in water maintained at the temperature of ordinary summer weather.] 


\section{C.-Pathogenous Species.}

12. M. vaccinæ, Cohn (l.c., p. r6r). Microsphara vaccine, Cohn.

Cells round, '5$75 \mu$ in diameter; isolated or united in chains and heaps of two or more, also forming a zooglœa. (Fig. 4a.)

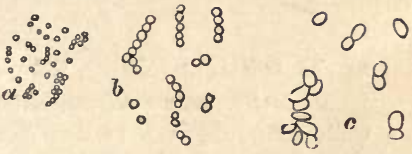

In fresh lymph from cow or human pocks, as also in the pustules of true small-pox.

According to many undoubted investigations, $M$. vaccince must be regarded as the active element of vaccine lymph; it is by its means that the infectious principle is conveyed in cases of small-pox. By filtering the lymph, the solid constituents can be separated from the fluid ; on using the latter for inoculation, no effect is produced, while inoculation by the former regularly excites the production of pocks. Moreover, that the Micrococci, and not, as might be suggested, the lymph-cells, are the effective constituents of the solid residuum, follows from the fact that lymph which has been exposed to the air for some time grows gradually less effective. For it begins to putrefy, and, as the process of decay advances, the Micrococci disappear more and more, under the influence of the putrefactive Bacteria.

13. M. diphtheriticus, Cohn (l.c., p. 162).

Cells oval, $3^{-1} \mu$ long; single or concatenate, or forming bundles and colonies of various shapes.

On the so-called diphtheritic membranes, which are found especially on the mucous surfaces of the throat, the pharynx, the air-passages, etc., but also appear on those of the sexual and digestive organs, as well as on wounds, etc.

This Schizomycete is of extraordinarily great pathological importance. For the disease spreads itself, from the centre of its first introduction, through the lymphatic vessels and the tissue which surrounds them, 


\section{2 Synopsis of the Bacteria and Yeast Fungi.}

into the connective tissue, the kidneys, and the muscular tissue; and at last reaches even the blood-vessels, where it produces the greatest destruction. The fungi stop up the capillaries and thereby rupture them. Even the thinner bones and cartilage are destroyed by the diphtheritic processes. The consequences of the introduction of these fungi are therefore enormous.

14. M. septicus (Klebs), Cohn (l.c., p. 164). Microsporon septicum, Klebs.

Cells roundish, $5 \mu$ in diameter; united in chains or heaps, or forming a zooglœa.

On wounds, especially in all the affections which are named pyæmia and septicæmia.

In the various suppurations and putrefactions of the body, in decomposition and poisoning of the blood, the Micrococci play an important part. Whether all the manifold phenomena are caused by $M$. septicus, or several species are not rather concerned in their production, is questionable. In wounds, even in the secretion from the fresh surfaces, we find Micrococci, which quickly multiply, produce inflammation and fever, and penetrate deeper and deeper, destroying the tissues in their course. If then they reach the blood-vessels, there arise stoppages and suppurations; the same phenomena are observed in the lungs and the liver.

15. M. bombycis (Béchamp), Cohn (l.c., p. 165). Microzyma bombycis, Béchamp.

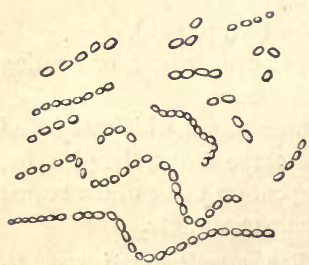

Fig. 5.-Micrococcus bombycis, from the gastric juice of a living silkworm (after Cohn).

Cells oval, $\cdot 5 \mu$ in diameter ; single or in chains. (Fig. 5.)

In the gastric juice and intestines of silkworms, in which they produce the so-called "schlaffsucht" (in French "la flacherie," one of the silkworm diseases), a contagious affection, of which the animuals die in a short time. 
[r6. M. insectorum, Burrill (l.c., p. 3 I9).

Cells obtusely oval, isolated or in pairs, rarely in chains, ${ }_{7-1} \mu$ (usually $\cdot 8 \mu$ ) long, $55 \mu$ broad; movements oscillatory only ; forming a zooglœa (?).

In the digestive organs of the chinch-bug (Blissus leucopterus).

These insects sometimes die off in great numbers during apparently favourable weather in summer, with every appearance of a contagious disease, and it is probable that this Micrococcus is the cause of the disease. It may be cultivated in meat broth.]

[17. M. gallicidus, Burrill (l.c., p. 320 ).

Cells globular, single or in pairs, ${ }^{\circ}{ }^{-} \cdot 72 \mu$ in diameter; movements oscillatory only.

In the blood of the domestic fowl affected with " chickencholera;" often described, but apparently never named before.]

[18. M. suis, Burrill (l.c., p. 320). Bacillus suis, Detmers.

Cells globular, or elongated and more or less contracted in the middle, single or in pairs, rarely in chains, $\cdot 7-\cdot 8 \mu$ in diameter.

In the blood and other fluids of pigs affected with "swine-plague " or "hog-cholera."]

Besides the diseases mentioned, it is probable that many others, e.g. cholera, measles, scarlet fever, typhus, syphilis, etc., are caused by Schizomycetous fungi. But no trustworthy observations are yet published concerning them. (See Appendix C.)

[An enormous number of other Micrococci have been described by Eberth, Chalvet, Hallier, etc., but for the most part without names and without precision. (See also Bacterium, Chapter IV., infra.)] 
14 Synopsis of the Bacteria and Yeast Fungi.

D.-Doubtrul Species.

19. M. griseus (Warming).

Bacterium griseum, Warming ("Om nogle ved Danmarks Kyster levende Bakterier," p. 29 of the Resumé).

- 8 Cells almost round or ovate, colourless, $2^{*} 5^{-4}$ $\mu$ long (in the act of division, $6-7 \mu$ long), $1 \cdot 8-$ $2.5 \mu$ thick. (Fig. 6.)

8 In infusions of fresh and sea water.

00

Since, according to Warming, this form occurs only in Fig. 6. $-M i$ - a motionless state (and then forming no zoogloea), and crococcus grisews, $X$ 660 (after Micrococcus than to that of Bacterium, I have placed Warming). it in the former.

20. M. ovatus (Lebert).

Panhistophyton ovatum, Lebert.

Nosema bombycis, Nägeli.

Cells oval, about twice as long as broad, rounded at both ends, about 4-5, rarely $6 \mu$ long, 2-3 (usually $2.5 \mu$ broad); isolated or united in pairs or little heaps. (Fig. 4c.)

In various organs of silkworms, their pupæ, and imagos.

It is questionable whether the described cells belong to a Schizomycete. They were first discovered by Cornalia at Milan, and named corpuscules ("corposcoli"); according to him they are found also, although sparingly and more by chance, in the blood of healthy silkworms. Afterwards, these corpuscules ("corpuscules de Cornalia ") were recognised as the cause of an epidemic disease of silkworms, called "gattine," or "pébrine."

Since the cells in their form and motionlessness agree very well with Micrococcus, I have ranged them here. 
[21. M. toxicatus, Burrill (l.c., p. 319).

Cells globular, single or in pairs, rarely in chains, ' $5 \mu$ in diameter; movements oscillatory only.

In species of Rhus (Sumach), believed to be the peculiar "poison" for which these plants are noted.

Transferred to the human skin, they multiply rapidly, penetrate the epidermis through the sweat-glands (?), and set up the well-known inflammation.]

\section{ASCOCOCCUS, Cohn ("Beiträge," i. p. I 54).}

Cells colourless, very small, round, united in enormous quantity into larger or smaller, globular or irregular families. Families often folded, the folds again crimped, surrounded by a firm, cartilagino-mucous capsule of a rounded form.

The value of Cohn's genus Ascococcus is, in my opinion, just as questionable as that of the similarly named one of Billroth; it is besides doubtful whether or not they are identical. Possibly Ascococcus is only a stage in the development of Micrococcus.

\section{A. Billrothii, Cohn (l.c., p. I 24).}

Families lump-like, $20-160 \mu$ in diameter, surrounded by a capsule as much as $15 \mu$ thick, covering the surface of the fluid in a thick floccose layer. (Fig. 7.)

Forming a membrane on a solution of acid tartrate of ammonia.

The colonies consist of a well-defined cartilaginomucous colourless envelope, in which either only one or several families are enclosed. The families are of very varied size and form, solid, composed of numerous extremely minute round cells. The Fungus produces in its nutrient fluid a peculiar

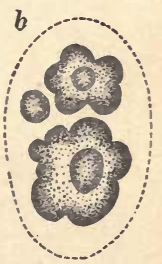

Fig. 7.-Ascococcus Billrothii (after Cohn). $b$, the investing capsule. decomposition; it generates out of the ammonic tartrate contained therein butyric acid and butyric ether, and changes the originally acid fluid into an alkaline one, while free ammonia is evolved. The liquid has then the characteristic smell of milk or cheese. 
III. LEUCONOSTOC,Van Tieghem (Ann. Sci. Nat., 1873).

[Cells colourless, very minute, globose ; united in flexuose and intertwined chains, which are enclosed in thick, lobed, gelatinous sheaths. Sheaths aggregated into subglobose, brain-like clusters, which present a pseudo-parenchymatous internal structure. Spores isolated in the chains, globose, terminal or intercalary.

This genus is distinguished from Ascococcus, in addition to the spores, by the fact that the families are not solid, each chaplet of cells being separated from its neighbours by a thick layer of gelatine. Its analogy to Nostoc is remarkable, the main difference being the want of chlorophyll. In fact, it bears the same resemblance to that genus that Cohnia does to Clathrocystis.]

[23. L. mesenterioides (Cienkowski), Van Tieghem. Ascococcus mesenterioides, Cienkowski.

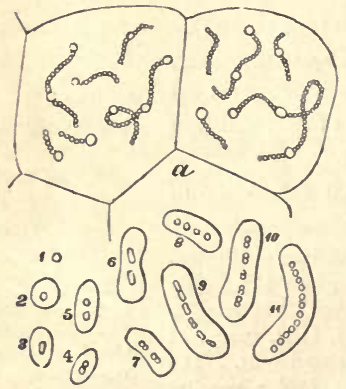

Fig. 8. - Leuconostoc mesenterioides, $\times 520$. $a$, section of a portion, showing the pseudoparenchymatous structure, and the inter. calary and terminal spores; $\mathbf{I - I I}$, a spore, and its development (after Van Tieghem).

Families collected in large masses, which may measure $I-I \frac{1}{2}$ inch across or more, polygonal by mutual pressure. Cells in long intertwined chains, colourless, spherical, $\cdot 8-\mathbf{r} \cdot \mathbf{2}$ $\mu$ in diameter; each chain surrounded by a thick gelatinous sheath. Spores spherical, with a thick membrane, $I \cdot 8-2 \mu$ in diameter. (Fig. 8.)

On beet-root sugar, and the sacks, vessels, etc., employed in the 
manufacture; can also be cultivated on macerations of dates and carrots, and in the juice of the same, and of beet, and has occurred spontaneously in the sap of turnips and in molasses.

This, the "gomme de sucrerie" of the French, "froschlaich," or frog-spawn, of the German sugar manufacturers, causes a great loss when it is allowed to take hold. It forms large whitish gelatinous masses, which grow very rapidly; the gelatine is elastic, almost cartilaginous, and insoluble in water. It renders acid the originally neutral liquid in which it develops. When a spore germinates, the middle layer of the cell-wall swells up, the spore proper elongates, and divides into two, which separate, and repeat the process. When the development has ceased, certain of the cocci increase in size, thicken their cell-wall, and become changed into spores. $-T_{R}$.]

\section{COHNIA, Winter: Clathrocystis (Henfrey), Cohn}

$$
\text { (pro parte). }
$$

Cells roundish, in a simple peripheral layer surrounded by a common gelatine, forming hollow', round or afterwards irregular bladders or vesicles, which finally are reticulately pierced. Multiplication of the cells by repeated bipartition; of the families by the protuberance and separation of daughter-families.

As I comprehend it, Cohn's genus, Clathrocystis, embraces both Algæ and Fungi. Since, then, the generic name was first used for an Alga ( $\mathrm{Cl}$. aruginosa, Henfrey), it is advisable to leave it for that species, and to make the species which belongs to the Fungi the type of a new genus, to which I have given the name of Cohnia, in honour of Professor Dr. F. Cohn, of Breslau, who has gained so much distinction in the investigation of the Schizomycetes.

24. C. roseo-persicina (Kützing).

Protococcus roseo-persicinus, Kützing.

Pleurococcus r.-p., Rabenhorst ; Cooke, "British Freshwater Algæ," p. 6.

Microhaloa rosea, Kützing.

Bacterium rubescens, Lankester, p.p. (Quart. Jour. 
Micr. Sci., xiii. 408, pl. 22-3; xv. 206; and xvi. 27, pl. 3).

Clathrocystis roseo-persicina, Cohn.

[Monostroma rosea, Currey.]

[Beggiatoa roseo-persicina, Zopf (pro parte).]

Cells round, oval, or, by mutual pressure, polygonal, varying from rose to purple-red, reaching $2 \frac{1}{2} \mu$ in diameter. They form at first small solid families, in which the single cells are bound together by gelatine, while the whole family is surrounded in addition by a gelatinous envelope. Later, the families become larger, globular or ovoid, and finally irregular bodies, which are hollow and filled with a watery fluid, and reach a diameter of $660 \mu\left(=\frac{2}{3} \mathrm{~mm}\right.$. or $\frac{1}{28}$ inch). In these the cells form a simple peripheral layer. These vesicles are often torn or perforated; in the end they present an elegant network, which finally breaks up into irregular rags and tatters. (Fig. 9.)

In marshes, floating on the surface or amongst Algæ and Lemna; often also in a room, in water in which Algæ, etc., are decaying.

The single hitherto known species of this genus is distinguished by its red colouring matter, which is essentially different from that of Micrococcus prodigiosus, and is designated "bacterio-purpurin." It is insoluble in water, alcohol, etc., is changed by hot alcohol into a brown substance, and is moreover characterised by its optical behaviour. For in the spectroscope it shows strong absorption in the yellow, less in the green and blue, as well as a darkening in the more refrangible half of the spectrum.* Each individual cell is surrounded by a dense, almost cartilaginous membrane; its contents are at first homogeneous, but as it grows older one or more dark granules $\uparrow$ can be observed in it, which are nothing else but pure eliminated sulphur.

[By the kindness of Mr. J. Levick, then President of the Birmingham

* For the spectrum, see Quart. Four. Micr. Sci., xiii. 425.-TR.

+ The granules are the "loculi " of Lankester, and the "spores" of other authors. $-\mathrm{T} R$. 


\section{0 Synopsis of the Bacteria and Yeast Fungi.}

Natural History Society, I have been favoured with specimens of a supposed Alga from his famous garden pond (the home of so many rarities), which $I$ at once recognized to be this species. It occurred in great quantity, floating freely in the water when young, but sinking among the débris at the bottom when old and tattered; its beautiful peach colour renders it very striking among the green Algæ with which it is frequently entangled. It was accompanied by Monas Okenii, Ehrenberg, which appears to be identical with Chromatium Weissii, Perty; but I could not find any other of the so-called forms of Bacterium rubescens, described by Lankester as occurring in company with it.-TR.]

\section{SARCINA, Goodsir (extended).}

Cells roundish, dividing in two or three dimensions of space. Daughter-cells connected for some time, forming small solid families or plates, which are often again in their turn united to form larger colonies. Families usually consisting of four or a multiple of four cells.

25. S. ventriculi, Goodsir (Edin. Med. and Surg. Journal, 1842, p. 430).

Merismopedia Goodsirii, Husem,

M. ventriculi, Robin.

Cells roundish, united in groups of four, eight, sixteen, or a few more, flattened at the points of contact, forming
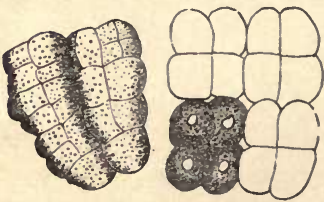

Fig. 10. Sarcina ventriculi, $X$ about 1300 (after Lürssen). little cubes which are rounded off at the corners. Individual cells reaching $4 \mu$ in diameter; colonies constricted at the partition walls of the cells, united in their turn to form larger masses. Cellcontents greenish, yellowish to reddish-brown, not conspicuously refringent. (Fig. IO.) 
In the stomach of healthy and diseased persons, and the higher animals; also occurring in other parts of the body, and according to Dr. Ferrier in the blood (Quart. Jour. Micr. Sci., xiii. 163).

26. S. urinæ, Welcker.

Merismopedia urina, Rabenhorst.

Cells very small, $\mathbf{I}_{\mathbf{2}} \boldsymbol{\mu}$ in diameter, united in families of from 8 to 64 ; eight-celled families $2.3 \mu, 64$-celled $4.5 \mu$ in diameter.

In the bladder.

27. S. litoralis (Ö̈rsted).

Erythroconis litoralis, Oërsted.

Merismopedia litoralis, Rabenhorst.

Cells round, or, before division, oval, $\mathbf{I}_{2} \mathbf{2} \mu$, seldom 2 or more $\mu$ in diameter, united into families of four, six, or eight, etc., which in their turn form larger colonies (as many as 64 groups of four in a colony). Plasma colourless, but in each cell from one to four red granules of sulphur. (Fig. Ir.)

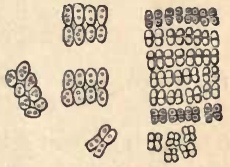

Fig. 11.-Sarcina litoralis, $\times 660$ (after Warming).

In putrefying sea-water.

28. S. Reitenbachii (Caspary). Merismopedium Reitenbachii, Caspary.

Cells round, before division ovate-elliptical, about $\mathbf{I}_{5} 5$ $-2.5 \mu$ in diameter, at the time of division prolonged to $4 \mu$; seldom single or in twos and threes, for the most part united in fours or eights, less often in sixteens or more. Cell-walls colourless, lined with a rose-red layer of plasma. 


\section{Synopsis of the Bacteria and Yeast Fungi.}

On submerged parts of water-plants, on decaying pieces of the same, and floating free in fresh water.

The families contain at most 32 cells; those consisting of 8 round cells measure $9^{\circ} 9 \mu$ in length, $4^{\circ} 9 \mu$ in breadth; plates of 8 cells in the act of separating are $6.6 \mu$ long, $4^{*} 9 \mu$ broad ; the same of 16 cells have a length of $16 \cdot 6 \mu$, and a breadth of 10.7 $\mu$.

Perhaps also Merismopedia violacea (Bréb.), Kützing, belongs to the Fungi. It agrees closely with $S$. Reitenbachii in size, but is distinguished by its colour, and especially by the fact that the cells are not unfrequently united in one family to as many as $\mathbf{1 2 8}$. Very similar but hitherto, I believe, only found in Sweden, is Merismopedium chondroideum, Wittrock.

29. S. hyalina (Kützing).

Merismopedia hyalina, Kützing. .

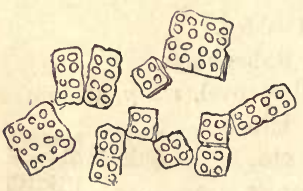

Fig. 12. - Sarcina hyalina, $\times_{420}$ (after Kützing).

Cells round, almost colourless, $2.5 \mu$ in diameter; families usually composed of from 4 to 24 (seldom more) cells, reaching I $5 \mu$ in diameter. (Fig. I 2.)

In marshes.

Sarcina renis, Hepworth (Microscopical Journal, v., 1857, p. I, pl. i. fig. 2), is coloured a lively green, and besides looks very little like a Sarcina, and shall therefore only be mentioned.

Besides the foregoing species of Sarcina, Fungi belonging to this genus have been observed on various substratra-on cooked potatoes (in little chrome-yellow heaps), on cooked white of egg (in clear yellow spots), also in fluids, even in the blood of healthy and unhealthy persons, and in the mouth.

\section{BACTERIUIM, Cohn ("Beiträge," i. p. I68).}

Cells shortly cylindrical, elongated-elliptical or fusiform, increasing by transverse division, spontaneously motile. The daughter-cells either separate from one another soon after division, or remain united in a chain of two or more. The formation of a zoogloa is also frequent. Spore-formation like that of Bacillus. 


\section{A.-Colourless Species.}

30. B. Termo, Dujardin ("Zoophyt.," p. 212).

Monas Termo, Müller.

? Palmella Infusionum, Ehrenberg.

Zoogloea Termo, Cohn.

Cells shortly cylindrical, oblong, about $\mathrm{I}^{\cdot 5-2} \mu$ long, with a flagellum at each end. (Fig. r 3.)

In the most various substances capable of putrefaction, especially in great numbers in macerations of meat, etc. [A supply $:-{ }^{\circ}, \because$, can be obtained in a few hours by placing a bit of meat in water, at a sufficient temperature.]

Bacterium Termo is the ferment of decay ; it produces the decay of organic substances, and multiplies

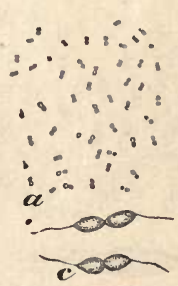

Fig. 13.-Bacterium Termo; $b$, the zoogloea form ( $a$ and $b$, after Cohn, $\times 650 ; c$, after Dallinger, $\times 4000$ ). abundantly so long as any putrescible material is present, while it disappears when the decay is completed. It may be obtained with certainty by putting a piece of meat into water, and leaving it to itself, allowing the vessel to stand open in a warm place. In consequence of their enormous power of multiplication, the Bacterium cells which are conveyed by the air into the fluid, or which adhere to the meat, form in a short time so numerous a progeny, that even in twenty-four hours the water shows a decided milkiness, which is caused by the Fungus cells floating in it. Moreover that $B$. Termo is the cause of the decay, and does not, as might be supposed, appear secondarily in the decaying substance, is easily shown by a simple experiment. For if the air is allowed to penetrate without hindrance to a putrescible substance, the decay begins very soon, because the air always contains a number of Bacterium cells. But if the putrescible organic substance is strongly heated (above $50^{\circ} \mathrm{C}$.) and then protected from the air, it does not 


\section{Synopsis of the Bacteria and Yeast Fungi.}

putrefy. It might indeed be objected that the air itself or the oxygen thereof causes the decay; but this objection also can be easily refuted. Air may be admitted to easily putrefying substances which have been strongly heated, but be deprived by filtration through cotton-wool of solid bodies (and therefore of Bacterium cells)-and in spite of the admission of air no decay will result.

31. B. Lineola (Müller), Cohn (l.c., p. r 70).

Vibrio Lineola, Müller.

$V$. tremulans, Ehrenberg (sec. Cohn!).

Bacterium triloculare, Ehrenberg.

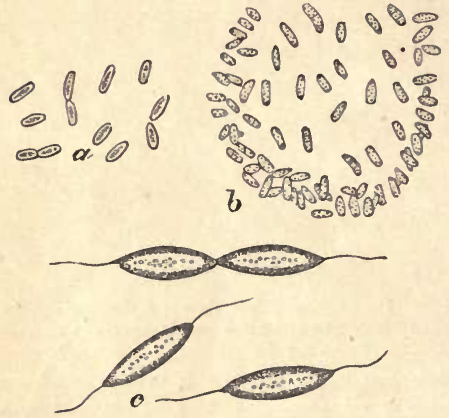

Fig. 14-Bacterium Lineola; $b$, the zoogloea form ( $a$ and $b$, after Cohn, $\times 6_{50} ; c$, after Dallinger, $\times 3_{3000}$ ).

Cells exactly similar to those of B. Termo, but larger, 3 to $5 \mu$ long, as much as I.5 $\mu$ broad, with two flagella at one end.* (Fig. 14.)

In various infusions, without especial fermentation.

32. B. litoreum, Warming

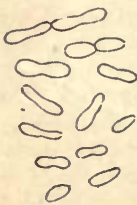

Fig. 15.-Bacterium litoreum, $\times 660$ (after Warming).

(l.c., p. 29 of the Resumé).

Cells ellipsoidal or elongated, gradually rounded off at the ends ; length $2-6 \mu$, breadth $\mathrm{I} \cdot 2-2 \cdot 4 \mu$; colourless, motile or stationary, but never united in chains or zooglœe, nor in large heaps. (Fig. 15.)

Only in sea-water.

* [The text says, "mit $z$ wei Geiseln an einem Ende;" but see the figures. - TR.] 
33. B. fusiforme, Warming (l.c., p. 30, Resumé).

Cells fusiform, with very acute ends, $2-5$ $\mu$ long, ' $5-\cdot 8 \mu$ thick, in a spongy layer on the surface of the water. (Fig. 16.)

In sea-water.

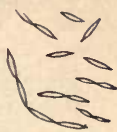

Fig. 16. - Bacterium, fusiforme, $\times 660$ (after Warming).

Cells fusiform or elliptic, narrowed towards both ends, pretty large, partly motile, partly stationary, with one or more dark spots in the interior, which are coloured blue by iodine. (Fig. I7.)

In rotting potatoes.

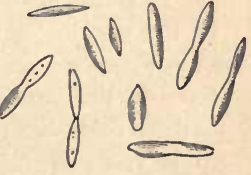

Fig. 17. - Bacterium Navicula, $X$ 940 (after Reinke and Berthold).

\section{B.-Chromogenous Species.}

35. B. synxanthum (Ehrenberg), Schröter, in Cohn (l.c., p. 120).

Vibrio synxanthus, Ehrenberg.

$V$. xanthogenus, Fuchs.

Morphologically not different from $B$. Termo; $7-1 \mu$ long, moving actively, single or united in chains up to five in number.

Causing the so-called "yellow milk."

Milk, which has been boiled, and some time afterwards coagulated, often suddenly assumes a lemon-yellow colour, while the caseine by degrees nearly disappears. The milk, originally neutral, becomes first acid, and then intensely alkaline. The filtered lemon-yellow fluid becomes amber-coloured on evaporation; the resulting yellow-brown crust is not soluble in alcohol or ether, but completely so in water. Alkalies do not affect the colour, which is instantly changed by acids. 
26 Synopsis of the Bacteria and Yeast Fungi.

35. B. syncyanum (Ehrenberg), Schröter (L.c., p. 124). Vibrio syncyanus, Ehrenberg.

$V$. cyanogenus, Fuchs.

Morphologically the same as the preceding.

Producing the "blue milk."

The colouring matter is changed by potash or soda into a peachblossom red, while acids restore the original colour. Ammonia, on the contrary, only slightly changes the blue to violet.

37. B. æruginosum, Schröter (l.c., p. 122).

In the so-called green or blue pus, which is at times found in wounds, etc. Resembling B. Termo.

Even in this case the actively moving Fungus cells are themselves colourless; they secrete the colouring matter, which is verdigris-green, often passing into blue, in the matter which surrounds them.

[38. B. violaceum (Bergonzini).

Chromobacterium violaceum, Bergonzini (Ann. Soc. Nat. Moden., xiv., r880; see Bot. Centralbl., i. 1528).

Rods isolated, motile, cylindrical, similar to those of $B$. Termo, ${ }^{\circ} 6-\mathrm{r} \mu$ thick, $2-3 \mu$ long, of a violet colour.

On solution of white of egg. Pigment insoluble in water, slowly soluble in ether, rapidly in alcohol. The ether dissolves out a red-violet colouring matter, the alcohol a deep blue one.]

\section{BACILLUS, Cohn (l.c., p. I 73).}

Cells elongated cylindrical, almost always combined in straight rod-like (not at all or slightly constricted) rows or threads, increasing by transverse division. They form a zooglœa, but often also occur in dense swarms, without the secretion of gelatine. Reproduction by spores. 
The genus Bacillus is very near to Bacterium; $\mathrm{Bac}$ terium Lineola especially is very similar to single Bacillus cells. But they can be distinguished by the fact that in the longer Bacterium cells self-division has already begun, while in equally long Bacillus cells no trace of division can be perceived.

The species are partly always motionless, partly spontaneously motile, passing however at times into a condition of rest. The rodlike cell lengthens itself by intercalary growth to about double its original length, and then breaks up by a transverse division into two daughter-cells, which often separate from one another, often also remain united. Since the products of repeated divisions are arranged end to end, there arise filaments which are often bent in a zigzag fashion, often also straight, apparently unjointed, but the joints may be brought into view by the application of staining materials. The development and germination of the spores in Bacillus has been already described. The demarcation of the different species is difficult in this case also.

\section{A.-Zymogenous Species.}

39. B. subtilis (Ehrenberg), Cohn (l.c., p. 175).

Vibrio subtilis, Ehrenberg.

Cells cylindrical, about twice as long as broad, as much as $6 \mu$ long, furnished with a flagellum at each end. Usually several united together in pseudofilaments, which are likewise motile, flexile, and

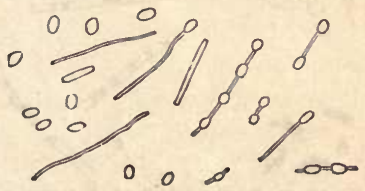

Fig. 18.-Bacillus subtilis, with spores (after Cohn). provided with a flagellum at each end. Spore-forming rods three or four times as long as broad, isolated or united in threads. Spores for the most part somewhat thicker than the rods. (Figs. I8, I9, 20a.) 


\section{Synopsis of the Bacteria and Yeast Fungi.}

In various infusions and substances; most probably also in the rennet-stomach of living animals.

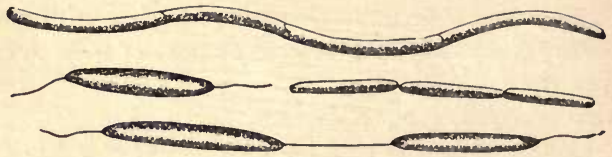

Fig. 19. - Bacillus subtilis, $\times 4000$ (after Dallinger).

According to Cohn, it produces the butyric fermentation and is also the efficient cause in the ripening of cheese.

An extraordinary and peculiar power of resistance is possessed by the spores of $B$. subtilis and other species. They are not killed off by boiling, but are thereby excited to speedier germination, which of course brings into consideration the duration of the boiling. A quarter of an hour's boiling does them absolutely no harm, while after an hour most of them, and after two hours all of them are killed. Heating them above $80^{\circ} \mathrm{C}$. kills them sooner. They are not affected by poisons and weak acids.

40. B. tremulus, Koch, in Cohn (l.c., ii. p. 4 I 7 ).

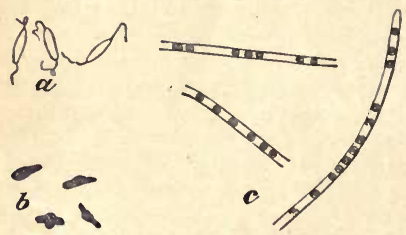

Fig. 20. $-a$, Bacillus subtilis; $b, B$. tremulus, with spores; $c, B$. anthracis, united in threads, forming spores, $\times 500$ (all after photographs by Koch).

Very similar to the preceding, but more slender and usually also shorter, always with a flagellum at each end. Spores conspicuously thicker than the cells, often lateral. 20b).

(Fig.

On the surface of decaying plant infusions, forming a thick gelatinous membrane. 


\section{I. B. Amylobacter, Van Tieghem (Bull. Soc. Bot. France, xxiv.). \\ [Clostridium butyricum, Prazmowski.]}

Morphologically like $B$. subtilis, but distinguished by the fact that at certain times it contains starch in its cells, which can be easily recognised by the blue colour produced on the addition of iodine.

In the cells of laticiferous plants, in decaying plant infusions, etc.

According to Van Tieghem's first communications, this species is the cause of cellulose-fermentation. Afterwards B. Amylobacter (and not $B$. subtilis) was indicated by him and Prazmowski (Bot. Zeitung, 1879, No. 26) as the ferment of butyric fermentation (Vibrion butyrique of Pasteur). According to Prazmowski, B. Amylobacter is especially and essentially distinguished from $B$. subtilis by the mode of germination of the spores. The germinating thread in the former species is protruded, not at the equator, but at one of the poles of the sphere. But it appears to me inadvisable to found a new species on this distinction, as Prazmowski desires.

[As little is known about B. Amylobacter in England, I append a passage of Van Tieghem concerning it, translated from the Bulletin of the Société Botanique de France, 1880, p. 284: "Ordinarily, as we know, when B. Amylobacter attacks starch-containing parenchyma, it first dissociates the cells by dissolving their intermediate lamellæ; then it causes the membranes of the cells thus separated to swell up, and dissolves them by degrees, without attacking the granules of starch which they enclose (as in potato, bean, etc.). In Adoxa Moschatellina it is quite different. The Amylobacter still begins, it is true, by destroying the intermediate lamellæ, and separating the cells, the punctations of which" (he is speaking of the sub-epidermal layer of the rhizome, macerating in water) " are then open to the outside. Penetrating into the cavity by one of these punctations, it proceeds to develop itself there among the starch granules. At the same time it attacks these granules, and causes them by degrees to disappear, without exercising any action upon the cellulose membrane. When it has completely dissolved and absorbed the grains of starch within the cell, the Amylobacter forms a brilliant spore in each of its articulations, and disappears. With its membrane unaltered, and the mass of spores which fills it, the cell then fulfils the part of a sporangium." According 


\section{Synopsis of the Bacteria and Yeast Fungi.}

to Van Tieghem, it is the action of this saprophyte which causes planttissues, immersed in water, to decay. $\mathrm{He}$ has even recognised the characteristic traces of its action in the remains of silicified fossil plants of the Carboniferous period; Ann. Sci. Nat. Bot., ix., 1879, p. 381 . $\left.-\mathrm{TR}_{\mathrm{R}}\right]$

42. B. Ulna, Cohn (l.c., i. p. I77).

Threads broader than in

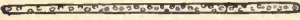
$B$. subtilis, slightly flexile, with

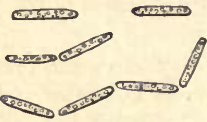

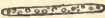

Fig. 21.-Bacillus Ulna (after Cohn).

a dense fine-grained plasma. Single cells as much as io $\mu$ long, $2 \mu$ broad. Spores oblong-cylindrical. (Figs. 21, 22.)

In various infusions, e.g. of white of egg.

Appears to be scarcely different from $B$. subtilis. Intermediate forms between the two have been observed.

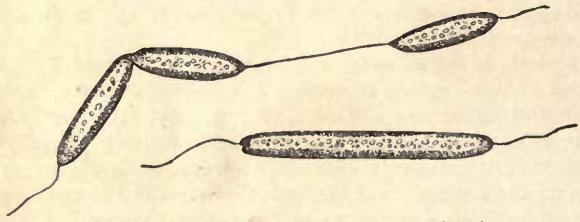

Fig. 22. - Bacillus Ulna, $\times 3000$ (after Dallinger).

B.-Pathogenous Species.

43. B. anthracis, Cohn (l.c., p. I77).

Exactly like $B$. subtilis, but motionless and without
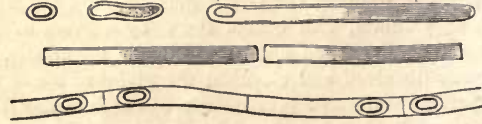

Fig. 23.-Development of Bacillus anthracis from a spore, and formation of spores in the threads (after Ewart). 
flagella; cells $4 \mu$ or more long, very slender, for the most part united into long, often bent, threads. Spores not at all or little thicker than the threads, $I^{\prime} 5^{-2} \cdot 2 \mu$ long. (Figs. $20 c, 23,24 a$.)

In the blood of animals which have died of splenic fever ;

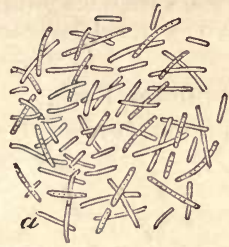

Fig. 24.- $a$, Bacillus anthracis, from the blood of a cow that had died of splenic fever, examined after death; $b, B$. ruber, $\times 600$ (after Cohn).

the cause of splenic fever in cattle, sheep, etc., and of " pustula maligna," woolsorters' disease, in man.

$B$. anthracis and the pathological phenomena engendered thereby are the most accurately known of all the diseases induced by Schizomycetes. The Bacilli are found without exception in the blood of animals which have died of splenic fever, and it is sought to infer that they are the cause of the disease. So long as only the vegetative threads were known, it was difficult to prove this; for these are capable of living only a relatively short time, and blood which contains them alone soon loses its power of infection. The remarkable thing about splenic fever, however, is that it often breaks out in a neighbourhood quite suddenly, then disappears for a long time, to appear again just as unexpectedly without any transference from without having taken place. From these facts it must be concluded that the contagium can preserve its infectiveness for a considerable time. The discovery of the spores of B. anthracis, which nevertheless are formed only in the blood of dead animals, or when the blood of animals affected with splenic fever is slowly dried, explains this long-lasting power. For, moreover, the spores of $B$. anthracis possess great capabilities of resistance to external influences, especially to dryness, so that they are capable of further development even after years. These spores are buried in the ground with the bodies of diseased animals which have died, and when there means of dispersion are open to them. If then they get in any way into the bodies or the blood of cattle, etc., they germinate, the rods which proceed from them multiply in abundance and soon commence their destructive work.

[This species is now known to move at one stage of its existence, 
and also to form a zoogloa (Quart. Four. Micr. Sci., xviii. 163). Klein describes, l.c., xxiii. 260, a torula-like variety which sometimes passed on the same thread into the typical Bacillus.-TR.]

[44. B. tuberculosis, Koch.

Rods slender, about one-half to one-third of a human

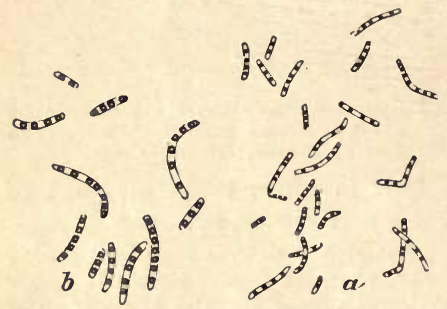

Fig. 25.-Bacillus tuberculosis, from human sputum, prepared by Heneage Gibbes's method; $\alpha \times 1200$; $b \times 1500$ red blood-corpuscle in length, i.e. $3^{-4} \mu$ long, and in breadth one-sixth of their length. Spores not thicker than the threads, about $5 \mu$ in diameter. 25.)

In the walls of tuberculous cavities, in the sputum, and even in the breath of phthisical patients, in degenerated scrofulous glands, in fungous joints, and in the bones of tuberculous animals (Koch), and in all kinds of tuberculous new formations (neoplasms).

This was first discovered by Koch, by staining with methylene blue in alcohol, followed by a solution of vesuvin; the methods of Ehrlich, Baumgarten, and Heneage Gibbes are given in the Appendix, p. 103.]

[45. B. lepræ, Hansen (Virchow, Archiv, I880, p. 32). Rods slender, resembling those of $B$. tuberculosis, but about $7 \mu$ broad. Spores not thicker than the threads. (Fig. 26.)

In the "lepra" formations of the skin, in the liver, the spleen, the testicles, the lymph-glands, the mucous membrane of the mouth, throat, etc., of leprous patients, 


\section{Bacillus.}

but, as it appears, not in the kidneys or the blood. The "brown elements" always found in old tubercles are pro-
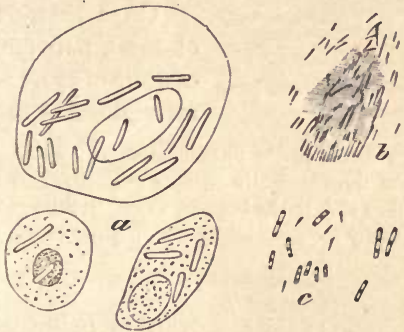

Fig. 26.-Bacillus lepre. $a$, cells from tubercles, fresh; $b$, a

" brown element" coloured with methyl-violet, from a tubercle treated with osmic acid; $c$, bacilli, with spores ( $a$ and $b$, after Hansen; $c$, after Neisser).

bably agglomerations of spores and spore-forming Bacilli. This species is acted upon by staining agents in the same way as $B$. tuberculosis.]

\section{C.-Chromogenous Species.}

46. B. ruber, Frank et Cohn (l.c., i. p. 18I).

Rods 6-8 $\mu$ thick, scarcely I $\mu$ thick, actively motile, isolated or united from two to four together. Dividing rods sometimes shorter, only 3-4 $\mu$ long. Secreting a brick-red pigment, which is different from that of $M$. prodigiosus. (Fig. 24.)

On boiled rice.

47. B. erythrosporus, Cohn (l.c., iii. p. 128 ).

Motile, short, slender rods, partly forming longer threads, 


\section{Synopsis of the Bacteria and Yeast Fungi.}

in which numerous oval-oblong, bright shining, dirty red-

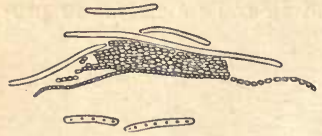

Fig. 27.-Bacillus erythrosporws (after Miflet). coloured spores arise. (Fig. 27.)

On a solution of extract of meat, putrefying infusions of white of egg, and putrefying macerations of meat.

This species forms partly little floating scales, partly continuous membranes; the threads finally dissolve to a jelly, thereby freeing the spores, which then sink to the bottom, united in little gelatinous heaps. The species is easily recognisable by the dirty-red colour of the spores.

\section{LEPTOTHRIX, Kützing ("Phycologia Gene-} ralis," p. 198), pro parte.

Threads very long and slender, unbranched, apparently inarticulate, colourless, without motion, not granular, free or felted together.

The Fungi assigned to the genus Leptothrix are of very questionable value as species; I therefore include the following with all reserve. Leptothrix-like formations are very common in Bacillus.

Since this genus will probably remain only a short time among the Fungi, I do not think it desirable to give it a new name now. The greater part of the species of Leptothrix are typical phycochromaceous Algæ !

48. L. buccalis, Robin ("Hist. Nat. Vég. Paras.," p. 345).

Threads very long and slender, ${ }^{-7-1} \mu$ (seldom somewhat more) thick, inarticulate, colourless, densely felted in white masses. (See also Fig. 27a.)

Mixed with Micrococci (usually also with Vibrio, etc.) in 
the white slime of the teeth, on the epithelium of the mouth, and in hollow teeth; probably the cause of dental caries.

The seat of this Fungus is especially in the canals of the dentine, yet it also attacks the substance of the enamel, which it destroys by degrees. In those canals the Fungus produces decided enlargements, and afterwards their walls become pierced by crevices and fissures, and break to pieces. [According to recent authors, the enamel must first be attacked by the acids of the mouth, before the Fungus can effect a lodgment.]

49. L. parasitica, Kützing (Bot. Zeit., 1847, p. 220).

Threads very slender, for the most part curled and crisped, indistinctly jointed, loosely felted, almost colour-

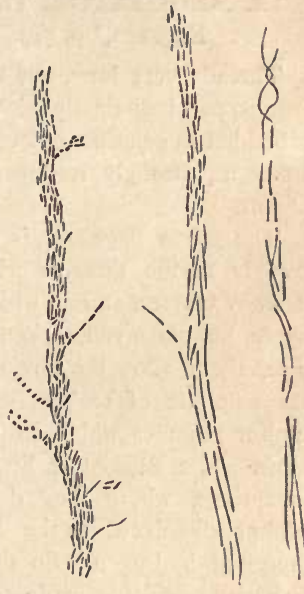

Fig. 27a.-Leptothrix buccalis (after Zopf). This is the form called Zooglaea ramigera. less, about I $\mu$ thick, roo-1 $40 \mu$ long. (Fig. 28.)

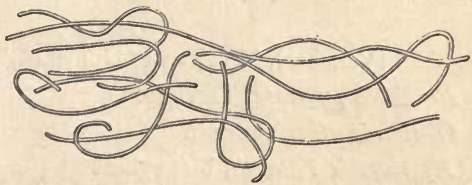

Fig. 28. - Leptothrix parasitica, $\times 600$ (after Kützing).

Parasitic on Scytonemaceæ and other allied Algæ.

Perhaps also Leptothrix pusilla, Rabenhorst, and L. Lanugo, Kützing, should be placed among the Fungi. 
IX. BEGGIATOA, Trevisan ("Prospetto della Flora Euganea," p. 76).

Threads very long, but thicker than in Leptothrix, for the most part indistinctly jointed, rigid, but actively oscillating, embedded in gelatine, colourless; protoplasm provided with numerous, strongly refringent granules, which consist of sulphur.

The genus Beggiatoa is easily to be recognised by the strongly motile threads, which form usually chalk-white or slimy masses, and in which the articulations cannot, as a rule, be perceived without further treatment. In order to see them, allow the threads to dry on the slide, and then add sulphide of carbon, which by degrees dissolves the sulphur granules which in the living Fungus obscure the joints. The Beggiatoæ live for the most part in sulphur hot-springs, where they decompose the compounds of sulphur dissolved in the water, and eliminate free sulphuretted hydrogen. So that such water, enclosed in a flask with Beggiatoa, evolves an intense smell of sulphuretted hydrogen.

The accepted species of Beggiatoa are of very doubtful value; they are discriminated almost entirely by the thickness of the threads.

50. B. alba (Vaucher), Trevisan ("Nomencl.," p. 58). Beggiatoa punctata, Trevisan. Oscillaria alba, Vaucher. Hygrocrocis Vandelli, Meneghini.

Threads without distinct articulations, forming dirty or chalk-white gelatinous masses, $3-3.5 \mu$ thick. (Fig. 29a.)

In sulphur springs and marshes. 
Var. marina, Cohn (B. Erstedtii, Rabenhorst). thick.

Threads densely filled with blackish granules, only $2 \mu$

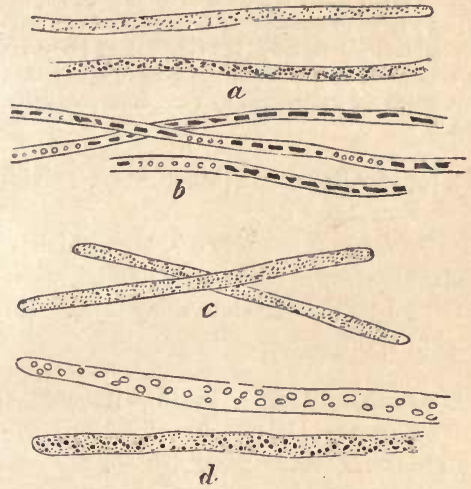

Fig. 29.-a, Beggiatoa alba, $\times 600 ; b, B$. nivea, with the plasma contracted, $\times 900 ; c, B$. leptomitiformis, $\times 800$; d, B. tigrina, $\times 800(a, c$, and $d$, after Kützing ; $b$, after Rabenhorst). The engraver has made these threads too thick, especially $c$.

Forming a delicate snowwhite gelatinous membrane on decaying animals and Algæ in an

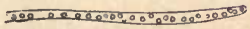
aquarium with sea-water. 3०.)

(Fig. Fig. 3o.-Beggiatoa alba, var. marina, $\times 660$ (after Warming).

51. B. nivea, Rabenhorst ("Flor. Eur. Alg.," ii. p. 94). Leptonema niveum, Rabenhorst.

Threads very slender, indistinctly jointed, $\mathbf{I}-\mathbf{I} \cdot 5 \mu$ thick (according to Rabenhorst), forming undulated woolly tufts of a chalk-white colour. (Fig. 29b.) 
38 Synopsis of the Bacteria and Yeast Fungi.

\section{In sulphur springs.}

In Wartmann and Schenk's "Schweiz. Kryptog.," No. 639, this species is published under the name of Symphyothrix nivea, Brigger. Both the names given above are cited as synonyms, but only pro parte. From the label attached I extrąct the following observations:- " Threads inarticulate and motionless, only $\frac{1}{4000}$ to $\frac{1}{1680}{ }^{\prime \prime \prime}$ thick $\left(={ }^{-} \cdot{ }^{-1} \cdot 3 \mu\right)$, parallel and much entangled, in penicillate tufts, strings, and sheaves of very unequal size, which are surrounded by a common, homogeneous, colourless gelatine."

52. B. leptomitiformis (Meneghini), Trevisan ("Flor. Eug.," p. 56).

Oscillaria leptomitiformis, Meneghini.

Threads very slender, indistinctly jointed, about $\mathrm{x} \cdot 8-2 \cdot 5 \mu$ thick, forming a thin chalk-white slimy layer. (Fig. 29c.)

In sulphur springs.

53. B. arachnoidea (Agardh), Rabenhorst ("Flor. Eur. Alg.," ii. p. 94).

Oscillaria arachnoidea, Agardh.

$O$. versatilis, Kützing.

Threads pretty thick, distinctly jointed, strongly motile,

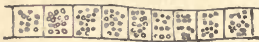

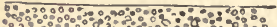
$\because 3$

Fig. 31.-Beggiatoa arachnoidea, $x$ 320 (after Warming).

In sulphur springs and marshes. with rounded slightly curved ends. Articulations as long or half as long as broad. Threads 5-6.5 $\mu$ thick, forming thin, arachnoid, chalk-whitegelatinous membranes. (Fig. 3r.)

\section{B. pellucida, Cohn (Hedwigia, I865, p. 82).}

Threads about $5 \mu$ thick, motile, distinctly jointed, with rounded ends ; articulations almost as long as broad, translucent, containing but few granules. (Fig. 32.)

In an aquarium with sea-water. 


\section{Beggiatoa.}

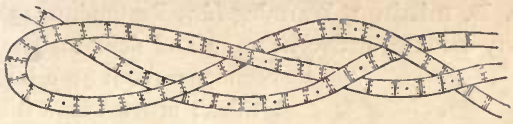

Fig. 32.-Beggiatoa pellucida, $\times 400$ (after Cohn).

55. B. mirabilis, Cohn (l.c., p. 8I).

Threads very thick, motile, bent and curled in various ways, with rounded ends, distinctly jointed, as much as I6 $\mu$ thick ; articulations about half as long as broad, filled with numerous, pretty large granules. Threads twisted round and entangled with one another, forming a snow-white web of gelatinous threads. (Fig. 33.)

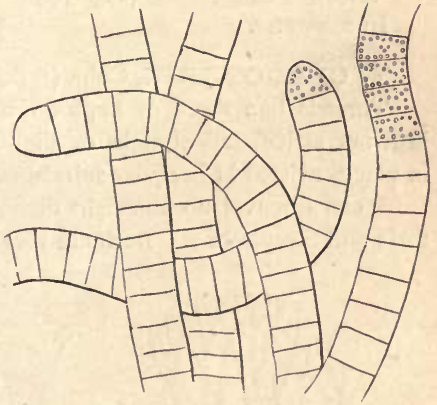

Fig. 33--Beggiatoa mirabilis, $X$ about 320 (after Cohn).

With the preceding.

\section{Doubtful Species.}

56. B. tigrina, Rabenhorst ("Flor. Eur. Alg.," ii. p. 95).

Oscillaria tigrina, Römer.

Threads pretty thick, oscillating, distinctly jointed, with blunt and slightly bent, sometimes abruptly attenuated and crooked ends, translucent, $3{ }^{\circ} 5-4{ }^{\circ} 5 \mu$ thick; forming thin white layers. (Fig. 29d.)

In marshes and on wood under water. 
40 Synopsis of the Bacteria and Yeast Fungi.

57. B. minima, Warming (l.c., Resumé, p. 15).

Very minute, actively motile and flexile. The longest

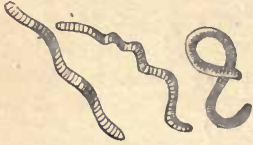

Fig. 34--Beggiatoa minima, $\times$ 660 (after Warming).

In sea-water. specimens about $40 \mu$ long, I $8-2$ $\mu$ thick; articulations discernible in the form of delicate transverse bars. Each joint about half as long as broad. Without granules. (Fig. 34.)

X. CLADOthrix, Cohn ("Beiträge," i. p. 204).

Threads like those of Leptothrix, very slender, colourless, not articulated, straight or slightly undulated, or even in places twisted in irregular spirals, with false branching.

I can discover no sufficient distinction between Cladothrix and Streptothrix. Both are very doubtful genera.

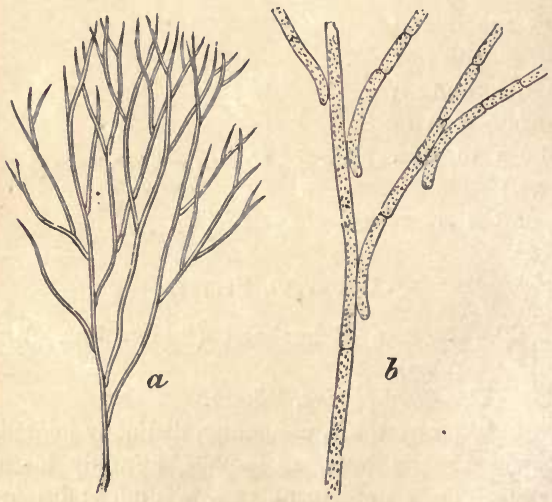

Fig. 35.- $a$, Cladothrix dichotoma, $\times 100 ; b$, a part of the same, showing the false dichotomy, $\times 600$ (after Cohn). 
58. C. dichotoma, Cohn ("Beiträge," i. p. 185).

Threads repeatedly and regularly dichotomously branched, straight or slightly bent, about $3 \mu$ thick, forming small tufts of $\frac{1}{2}$ or more $\mathrm{mm}$. in diameter. (Fig. 35.)

In putrid water, partly floating on the surface, partly attached to Algæ.

The branching is here, just as with C. Försteri, only apparent. A thread splits itself down the middle into two halves, which lengthen independently, and thus grow side by side, whereby the piece which was separated is pressed on one side, and so appears as a branch.

59. C.Försteri (Cohn.) Streptothrix Försteri, Cohn (" Beiträge," i. p. r86).

Threads straight or bent, in places twisted in irregular spirals, sparingly and irregularly branched, separating into pieces of various lengths. (Fig. 36.)

In the lachrymal canals of the human eye, forming tallowy or crumbling masses, which are yellowish-white or blackish, I $\frac{1}{2}-3^{\prime \prime \prime}$ long, and about $\mathbf{x}^{\prime \prime \prime}$ (i.e. about $2 \mathrm{~mm}$.) thick.

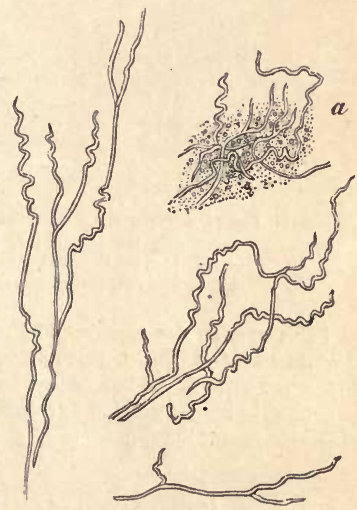

Fig. 36.-Cladothrix Forsteri, $\times 600 . a$, the threads embedded amongst Micrococci (after Cohn).

XI. MYCONOSTOC, Cohn ("Beiträge," i. p. I83).

Threads very slender, colourless, inarticulate, but on desiccation breaking up into short cylindrical fragments, 


\section{Synopsis of the Bacteria and Yeast Fungi.}

variously bent and intertwined, surrounded by gelatine, which forms spheroidal masses of ro-1 $7 \mu$ (or more) in diameter. Multiplication by constriction and bipartition of these gelatinous masses.

6o. M. gregarium, Cohn (l.c.).

Gelatinous masses floating on the surface of putrid water, singly or heaped into little slimy drops; exterior boundary sharply defined. (Fig. 37.)

On water in which Algæ were decaying.
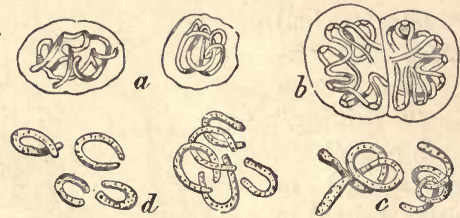

Fig. 37.-Myconostoc gregarium. a, gelatinous sphèroids, containing the threads; $b$, a spheroid in the act of division; $c$, the threads separated; $d$, the threads breaking up into ring-shaped pieces (after Cohn).

[This species was recorded by Professor Lankester as a phase of Spirillum Undula (Quart. Four. Micr. Sci., xiii. 424), but as no genetic connection between the two has yet been traced, Cohn thinks it better, at present, to keep it distinct. It derives its name from its resemblance to Nostoc among the Algæ. (Fig. 38.)-TR.]

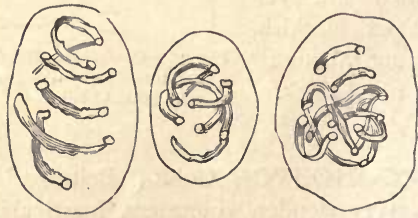

Fig. 38.-Myconostoc gregarium, $\times$ I500 (after Lankester, who considers it a zoogloea form of Spirillum Undula). 
XII. SPIROCH ÆrTA, Ehrenberg (Abhandl. Berlin. Akad., r833, p. 3r3).

Cells united in long slender threads, which present $a$ considerable number of close spiral turns. The threads are very actively motile; in fact they swim forwards or backwards, rotating round their longitudinal axes, and can moreover bend themselves in the most varied manner. Not forming a zooglœa, but often felted in dense tufts.

Distinguished from Spirillum by the long, closely wound, flexile threads.

6r. S. plicatilis, Ehrenberg (l.c., p. 313).

Spirillum plicatile, Dujardin.

Spirulina plicatilis, Cohn.

Threads very short and slender, with numerous close spirals, articulated, blunt at the ends, rro-225 $\mu$ long (according to Rabenhorst); diameter of the single joints (and thickness of the threads) $\mathbf{2} \cdot 25 \mu$, according to Ehrenberg. [Spores, according to Van Tieghem, $8 \mu$ in diameter.] (Fig. 39.)

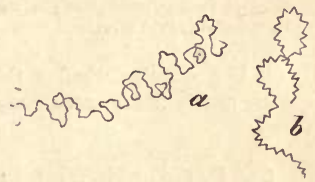

Fig. 39.-Spirochata plicatilis ( $a$, after a photograph by Koch; $b$, after Cohn).

In bog-water, among Algææ.

This species is said by Koch to be distinguished from the others especially by the doubly undulated contour of its filaments. But still filaments with a simple spiral are very abundant. [Dr. Klein (Quart. Four. Micr. Sci., xv. 382) asserts that he has seen all intermediate forms between this and Spirillum tenue, with which he unites it.-TR.]

62. S. Obermeieri, Cohn ("Beiträge," i. p. r96). Morphologically almost the same as $S$. plicatilis, perhaps 
only distinguished by the fact that the threads are pointed at both ends. (Fig. 40.)

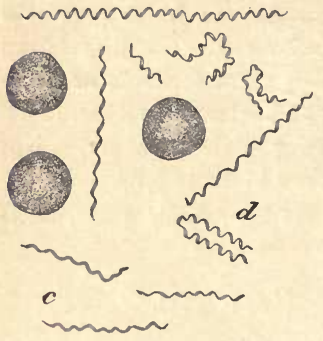

Fig. 40.-Spirochata Obermeieri. (c, after a photograph by Koch; $d$, after Weigert). In $d$ the blood corpuscles are represented; the bent threads show the form assumed shortly before the cessation of the fever.

In the blood of persons suffering from febris recurrens, and probably the cause of the disease.

The threads of $S$. Obermeieriare either extended in a straight line, and wound in regular spirals, or else they bend themselves, moving with extreme rapidity in the most varied fashion, so that the spirals appear of unequal size, especially at the most strongly bent places. This species is found in the blood of those suffering from intermittent fever, and in fact only during the recurring fever periods, or for a short time thereafter. In the intervals of freedom from fever they disappear.

[It is a question whether this be not the same as the preceding species, merely transplanted into a different habitat.-TR.]

63. S. Cohnii, Winter ("Pilze," i. p. 6r, r884). [Spirochate denticola, Arndt.]

[S. dentium, Miller.]

Very similar to both the foregoing species, but always shorter, and for the most part more

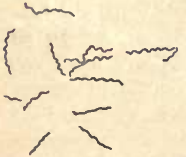

Fig. 4I. - Spirochata Cohrii (after Koch). slender, than $S$. Obermeieri, and besides, like that, pointed at both ends. (Fig. 4r.) In the slime of the teeth; discovered by Cohn ; figured by Koch (" Beiträge zur Biologie," vol. ii. pt. 3, pl. xiv. fig. 8). [Miller has shown that this is articulated, like $S$. plicatilis.] 
64. S. gigantea, Warming (l.c., Resumé, p. 2 I).

Threads cylindrical, blunt at both ends, about $3 \mu$ thick, with numerous spiral turns, the height of which is $25 \mu$, the diameter $7-9 \mu$. Flexile. The articulations are not

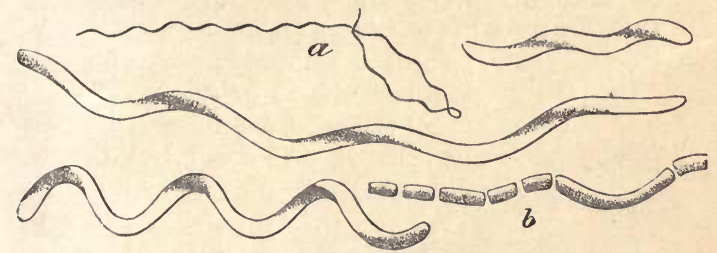

Fig. 42.-Spirochata gigantea; $a, \times_{166 ;} b, \times 660$ (after Warming).

visible, but at times the threads break up into joints. Colour greyish. (Fig. 42.)

In sea-water.

The longest specimens showed sixteen turns; flagella have not been discovered.

. XIII. SPIROMONAS, Perty ("Zur Kenntniss der kleinsten Lebensformen," p. I 7 I).

Threads "flattened like a leaf, twisted round an imaginary longitudinal axis." Multiplication by transverse division.

65. S. volubilis, Perty (l.c.).

"Colourless, translucent [rounded at both ends], smooth, without any obvious differentiation, motion pretty swift, combined with a quick revolution round the axis about which the leaflike body is twisted. Body often twisted very little, never forming more than a circumference. Length $\frac{1}{120}-\frac{1}{160}{ }^{\prime \prime \prime}=15-18 \mu$." (Fig. 43.)

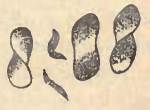

Fig. 43.-Spiromonas volubilis, $x$ about 450 (after Perty). 


\section{Synopsis of the Bacteria and Yeast Fungi.}

In stagnant bog-water and putrefying infusions.

[This is often considered as an Infusorian. See Saville Kent's "Manual of the Infusoria," p. 298. -TR.]

\section{S. Cohnii, Warming (l.c., Resumé, p. 20).}

Cells flattened, but sometimes slightly angular, acutely pointed at both ends, each with one

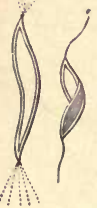

Fig. 44. - Spiromonas Cohnii, $\times 660$ (after Warming). flagellum, with $\mathrm{I}_{\frac{1}{4}}$ (seldom more) turn. Spiral elongated, 6-9 times as high as its diameter, $9-20 \mu$ in height, $\mathbf{x} \cdot 2-3 \cdot 5$ $\mu$ in diameter. Breadth of the cells $x^{\cdot 2-4} \mu$. Colourless, often with one or two longitudinal striations. 44.)

(Fig.

In stinking, very much decomposed water.

XIV. SPIRILLUM, Ehrenberg (Abhandl. Berlin. Akad., 1830, p. 38).

(Vibrio, Cohn ; Ophidomonas, Ehrenberg.) .

Cells cylindrical or slightly compressed, simply arcuate or spirally twisted, rigid, with a flagellum at each end (? whether in all species). Multiplication by transverse division, the daughter-cells for the most part soon separating. At times also a zooglœa is formed. Spore-formation similar to that of Bacillus.

I unite with the genus Spirillum, the Vibrio of Cohn, and the Ophidomonas of Ehrenberg. The genus Vibrio, in fact, cannot be sharply defined, since flagella have also been found in it. Cohn himself has already united Ophidomonas with Spirillum. Warming also combines all three genera. Although the name Vibrio has priority, still I have preferred the designation Spirillum, because gross misuse has been made of the former, especially by non-botanists, so that it is better to let it lapse altogether. 
67. S. Rugula (Müller).

Vibrio Rugula, Müller ("Infus.," p. 44).

Melanella flexuosa, Bory.

Cells 6-r6 $\mu$ long, about ${ }^{5}{ }^{-2} \cdot 5 \mu$ thick, either only simply arcuate, or with one shallow spiral, bearing a flagellum at each end, actively rotating round its longitudinal axis; the cells are often felted in dense swarms. Height of the spiral generally 6-ro $\mu$, diameter $5^{-2} \mu$. Spores always at the end of the cell, globose. (Fig. 45a.)

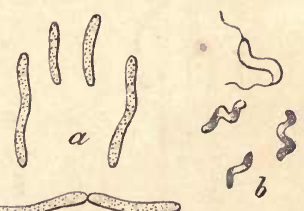

In bog-water, and various infusions; also in the slime of the teeth, etc.

According to Warming, individuals occur the spiral of which reaches a height of $13^{-20} \mu$ and a diameter of $2 \cdot 5-5 \mu$. Plasma granular.

68. S. serpens (Müller).

Vibrio serpens, Müller ("Infus.," p. 44).

Cells half as broad as in the foregoing species, $1 \mathrm{r}-28$ $\mu$ long (according to Rabenhorst), $8-r \cdot \mathbf{r} \mu$ thick, with several, usually three or four, spirals ; often united in long chains; with a flagellum at each end. Also frequently forming swarms. Height of the spirals 8-12 $\mu$, diameter r.2-3 $\mu$. (Fig. $46 a, b$.)

In various infusions.

The dimensions recorded by Rabenhorst ( $23-28 \mu$ long) presumably refer to threads composed of several cells. According to Warming, the herighrof the spirals is sometimes as much as $22 \mu$. , 

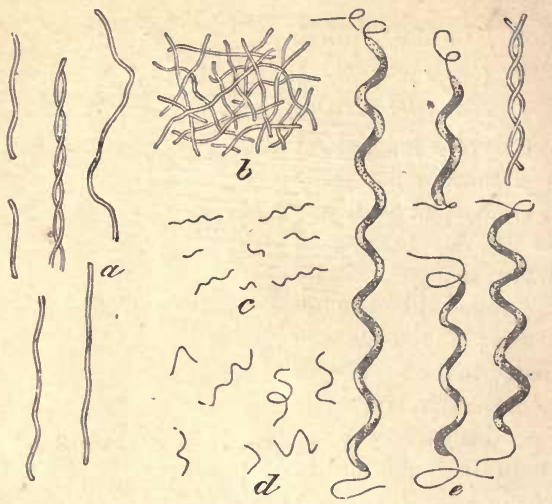

Fig. 46.-a, Spirillum serpens; $b$, the same, felted in a "swarm;" c, S. tenue; d, S. Undula; e, S. volutans, $\times 650$ (after Cohn).

69. S. tenue, Ehrenberg ("Die Infusionsthịerchen.," p. 84).

Cells very slẹnder, $4^{-15} \mu$ long, about $2.25 \mu$ thick

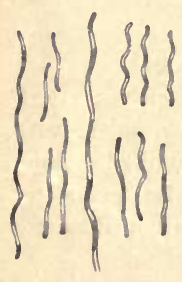

Fig. 47. -Spirillum tenue, $\times 660$ (after Warming). (according to Ehrenberg), with at least $\mathrm{I} \frac{1}{2}$, usually, however, $2,3,4$, or 5 spirals. Height and diameter of the spirals about I. 5-4 $\mu$, or the diameter amounts to half the height. Moving very swiftly, but also often almost motionless and felted in dense swarms or masses, or united in a zooglœa. (Figs. 46c, 47.)

In various infusions.

According to Warming, only I $\mu$ thick, and the spirals at times 8-10 $\mu$ high, with the diameter $\frac{1}{8}-\frac{1}{10}$ of the height. There appears to be some confusion between S. tenue and S. Undula. 


\section{Los Angeles, Cal.}

\section{Spirillum.}

70. S. U̦ndula (Müller), Ehrenberg (Abhandl. Berlin. Akad., 1830, p. 38).

Vibrio Undula, Müller.

$V$. prolifer, Ehrenberg.

Cells 8-I $2 \mu$ long, $\mathrm{I} \cdot \mathrm{I}-\mathrm{I} \cdot 4 \mu$ thick (according to Rabenhorst); spirals wider than in the foregoing, $4-5 \mu$ high; each cell for the most part embracing only $\frac{1}{2}$ or $\mathbf{I}$, seldom
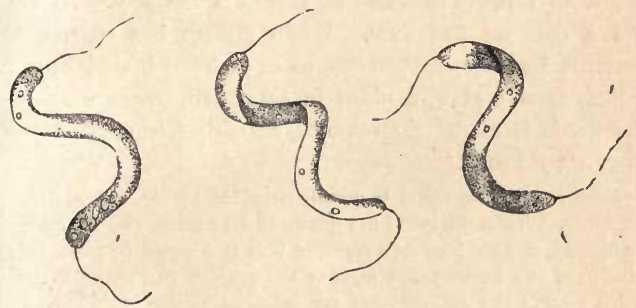

Fig. 48. - Spirillum Undula, $\times 3000$ (after Dallinger).

I $\frac{1}{2}$ to 2 or 3 spirals; a flagellum at each end. Very actively motile, at times also forming a zooglœa. (Figs. $\left.45^{b}, 46 d, 48.\right)$

\section{In bog-water and various infusions.}

Ehrenberg gives for $S$. tenue a thickness of $\frac{1}{1000}$ of a line, for $S$. Undula only Tobo of a line; at the same time, he says in the description, "Sp. fibris valde tortuosis brevibus, validioribus."

According to Warming, S. Undula is more variable than was formerly admitted. The spirals are often elongated, so that the cell appears almost straight; accordingly the height of the spirals varies from 3 to $10.5 \mu$, the diameter amounts to $\frac{3}{3}$, or $\frac{1}{10}$ of the height, the thickness of the cells $\cdot 6-1 \cdot 3 \mu$.

Var. litorale, Warming (l.c., Resumé, p. 23).

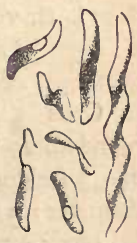

Fig. 49. - Spirillum Undula, var. litorale, $\times 660$ (after Warming). 
As much as $3 \mu$ thick, spirals elongated, each $5^{-10} \mu$ high, diameter $\frac{1}{5}$ or $\frac{1}{6}$ of the height.

On the shores of the Baltic Sea.

(Fig. 49.)

[7 r. S. amyliferum, Van Teighem (Bull. Soc. Bot. France, 1879, p. 66).

Motile. Spiral of $2-4$ turns, diameter of spiral 3-4 $\mu$, height $6-9 \mu$. Thickness of thread $\mathbf{r}^{\cdot}{ }^{2}-\mathbf{I}{ }^{\circ} 5 \mu$. At each end a delicate flagellum. When growth has ceased, the contents become amylaceous, so as to be coloured blue by iodine, except at one place in each cell, where a spore is afterwards formed. Spores oval, strongly refringent, $2 \cdot 5-3 \mu$ long, $\mathrm{I}^{\circ} 5 \mu$ broad.

Each turn of the spiral is usually occupied by one cell, and forms one spore. When the spiral has grown to four turns, two lateral septa are formed, and the four cells separate into two equal portions, by the solution of the intermediate layer of the median partition. While in active growth the cell-contents are coloured yellow by iodine. The spores are always placed at the end of a cell. In germinating, they throw out a tube, which soon becomes curved, and then spiral. When it has taken two turns, a central partition is formed. The similarity of this to the formation and germination of a Bacillus spore is noticeable; $S$. amyliferum is most probably only a phase of B. Amylobacter, in company with which it was found.]

72. S. volutans, Ehrenberg (Abhandl., 1830, p. 38). Vibrio Spirillum, Müller. Melanella Spirillum, Bory.

Cells slightly attenuated towards the ends, gently rounded, $25-3 \circ \mu$ long, about $r^{\cdot} 5^{-2} \mu$ thick; each cell with $2 \frac{1}{2}-3 \frac{1}{2}$ (seldom more) spirals, the spiral $9-13 \mu$ high, $6.5 \mu$ in diameter; a flagellum at each end. (Fig. 46e.)

In various infusions, as well as in bog-water among Algæ.

According to Warming, the spirals are often elongated, so that the cell appears almost straight; the diameter then amounts to only $1 \cdot 5-4 \mu$. 
Var. robustum, Warming (l.c., Resumé, p. 23).

Thickness $2-4.5 \mu$, height of the spirals ro-20 $\mu$, diameter $I-3 \mu$. Usually with $I \frac{1}{2}$ turn. Sometimes with two flagella at one end. (Fig. 50.)

In sea-water.

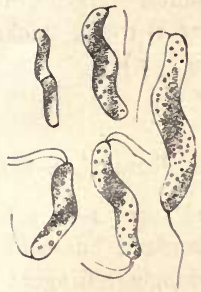

Fig. 50.-Spirillum volutans, var. robustum, $\times$ 660 (after Warming).

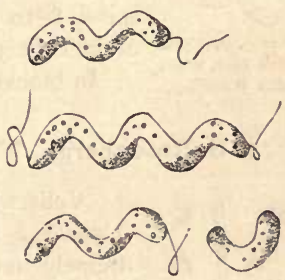

Fig. 5r.-Spirillum sanguineum, $\times 600$ (after Koch).

73. S. sanguineum (Ehrenberg), Cohn ("Beiträge," i. p. 17 r).

Ophidomonas sanguinea, Ehrenberg.

Cells cylindrical, only seldom attenuated at the ends, $3 \mu$ or more thick, of various lengths, with usually 2 (seldom $\frac{1}{2}$ or $2 \frac{1}{2}$ ) spirals. Height of the spirals 9-12 $\mu$, diameter about $\frac{2}{3}$ of the height; a flagellum at each end. Cellcontents coloured by numerous reddish bodies, with many sulphur granules. (Fig. 51.)

In putrefying brackish water [and pond water?].

According to Warming, the longest specimens reach $65 \mu$; the height of the spirals $15-37 \mu$, while the diameter amounts to $\frac{1}{2}$ or $\frac{2}{3}$, or in small specimens $4-\frac{1}{14}$ of the height.

[According to Saville Kent, the Ophidomonas sanguinea of Ehrenberg is a true monad, and not identical with Cohn's Spirillum sanguineum. (See "Manual of the Infusoria," p. 244, and infra, p. 94.)-TR.] 


\section{Sy'nopsis of the Bacteria and Yeast Fungi.}

74. S. violaceum, Warming (l.c., Resumé, p. 5).

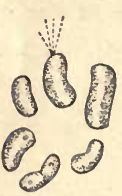

Fig. 52.-Spirillum violaceum, $\times 660$ (after Warming).

Cells either crescent-shaped (and so without a complete turn) or with $I$ or $1 \frac{1}{4}$ spiral, broadly rounded at the ends, with a flagellum at each. Cell-contents violet, with a few sulphur granules. Height of the spiral 8-Io $\mu$, diameter $\mathbf{I}-\mathbf{I} 5 \mu$, thickness of the cells $3-4 \mu$. (Fig. 52.)

In brackish water.

75. S. Rosenbergii, Warming (l.c., Resumé, p. Ix).

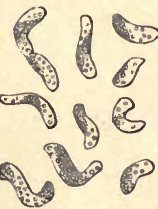

Fig. 53.- Spirillum Rosenbergii, $\times 660$ (after Warming).

Cells with $\mathrm{I}$ or $\mathrm{I}_{2}^{1} \mathrm{t}$ turn, $4^{-12} \mu$ long, ${ }^{1} \cdot 5^{-2} \cdot 6 \mu$ thick, colourless, but with extremely numerous strongly refringent sulphur granules. Spirals $6-7.5 \mu$ high, of very varied diameter, which amounts at the most to half of the height. Moving actively and in the most varied fashion, but, as it seems, without flagella. (Fig. 53.)

In brackish water.

76. S. attenuatum, Warming (l.c., Resumé, p. 25).

Cells strongly attenuated at the ends, usually with 3

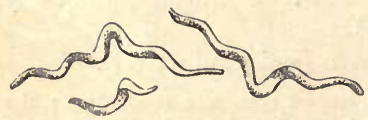

Fig. 54-Spirillum attenuatum, $\times 660$ (after Warming). spirals. The middle spiral is large and close (height about II $\mu$, diameter $6 \mu$ ), the end spirals are elongated ( $10 \mu$ high, $2 \mu$ in diameter). Thickness of the cells 2 or $\mathrm{x} \cdot 2 \mu$. (Fig. 54.)

In sea-water. 
77. S. Jenense (Ehrenberg).

Ophidomonas Jenensis, Ehrenberg ("Infusionsthierchen," p. 44)

Cells obtuse at both ends, with flagella, olive-brown, $40 \mu$ long, about $3 \frac{1}{3} \mu$ thick, with $\frac{1}{2}-2 \frac{1}{2}$ spirals. (Fig. 55.)

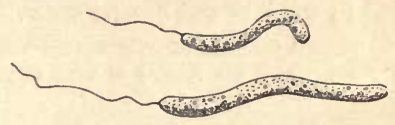

Fig. 55--Spirillum $\mathcal{F}_{\text {enense, }} \times 600$ (after Ehrenberg).

Whether this is really a distinct species is hard to say, so long as it is not found again in the original locality. Possibly it is identical with $S$. volutans.

[Saville Kent classes this as a true monad (see "Manual of the Infusoria," p. 244). Warming thinks it may be identical with $O$. sanguinea.-TR.]

\section{Appendix.}

With the Schizomycetes we may range several other genera which are partly united with them by others without remark, but which present so great peculiarities that it will be better provisicnally to separate them.

\section{SPHÆROTILUS, Kützing.}

Cells roundish-angular or oblong, rounded at the corners, united in great numbers in a colourless gelatinous sheath to form long threads, which are densely tufted and entangled in floating flakes. Multiplication by means of vegetative cells, which isolate themselves and then form new threads by continued subdivision. Reproduction by spores, which are produced endogenously within the vegetative cells.

78. S, natans, Kützing (Linnaa, 1833, p. 385).

Flakes in the vegetative stage yellow-brown in the 


\section{Synopsis of the Bacteria and Yeast Fungi.}

older parts, colourless in the younger, many times branched, very slimy. During spore-formation, partly- milk-white, partly red-coloured. Cells $4-9 \mu$ long, $3 \mu$ thick. (Fig. 56.)

In stagnant and flowing water.

The flakes consist of an enormous mass of long, variously combined threads, which are formed of rows of cells, surrounded by a slimy,

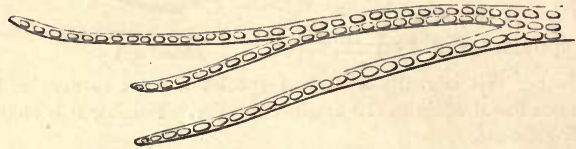

Fig. 56.-Spharotilus natans (after Kützing).

evanescent sheath. These threads often assume a shrubby branched form, and are attached to water-plants, or float in a thin layer on the water. In the formation of spores, the protoplasm of the cells breaks up into numerous minute, strongly refringent portions, which become round spores, red at maturity, afterwards of a brown colour. These are set free by the dissolution of the mother-cell. They germinate very quickly, and grow into threads which are either isolated, or united with the parent-threads or with other threads as well. These daughterthreads, proceeding from the germinating spore, are at first undivided; not till after a time do they break up into the typical rows of cells. Sometimes the growth of the spores into threads takes place while they are still within the mother-cell.

Spharotilus ochraceus, de Brébiss in litt., Kützing, "Species Algarum," p. 147, does not belong to this genus.

\section{CRENOTHRIX, Cohn.}

Threads cylindrical, somewhat clavately thickened upwards, articulated, provided with a sheath. Multiplication by means of the joints, which escape from the sheath and grow into threads. Reproduction by spores, which are formed in the sheath by further subdivision of the joint-cells. The spores either grow directly into threads, or form by continued subdivision gelatinous colonies of roundish cells, which afterwards produce threads. 
79. C. Kühniana (Rabenhorst), Zopf ("Untersuch. über Cren." (1879), p. 3).

Leptothrix Kühniana, Rabenhorst.

Hypheothrix Kühniana, Rabenhorst.

Crenothrix polyspora, Cohn.

? Palmellina flocculosa, Radlkofer.

Threads in whitish or brownish tufts, $I^{\cdot} 5-5 \mu$ thick,

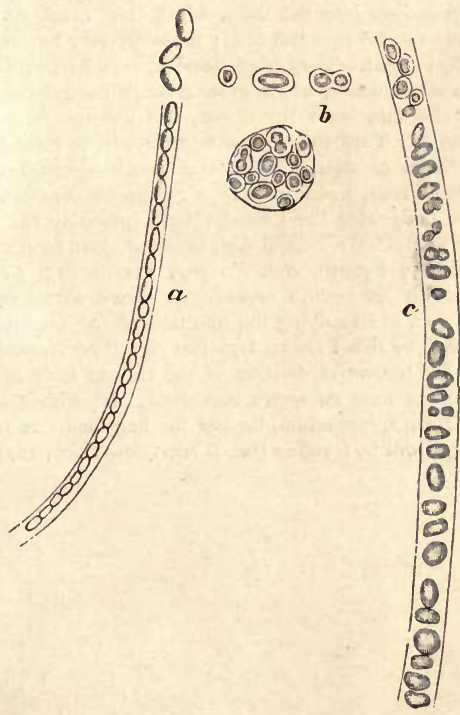

Fig. 57.-Crenothrix Kühniana (after Zopf). a, vegetative threads; $b$, Palmella form; $c$, spore-forming threads.

increasing to $6-9 \mu$ towards the end; joints of very varied lengths. Spores $1-6 \mu$ in diameter.

(Fig. 57.)

In wells and drain-pipes, etc. 


\section{Synopsis of the Bacteria and Yeast Fungi.}

A Fungus which is often very troublesome, because it defiles the water and stops up the narrower pipes. The cylindrical threads, somewhat clavate above, are visibly articulated; the joints afterwards separate from one another, but are then surrounded by a sheath, which, originally colourless, becomes of a yellow or yellowish-brown colour by impregnation with iron. The sheath, at first closed, is burst at last by the continually dividing joints, which then escape. Each joint can develop a new thread. In other cases, however, the thread remains enclosed in the sheath; its joints are divided by closely contiguous transverse partitions into flat discs, which then break up by vertical partitions into smaller roundish cells : the latter may be designated the spores of the Fungus. They often develop, even while still within the sheath, into new threads, which grow through the gelatinous swollen sheath; or else they leave the sheath, and undergo further development outside it. They either grow into threads, or form by repeated bipartition larger or smaller colonies of roundish cells, held together by their membranes, which assume a gelatinous consistence. These colonies are designated the Palmella form (probably the Palmellina flocculosa of Radlkofer); each of their cells can again form a thread.

[According to Eyferth, Bot. Zeitung, xxxviii. 673, C. Kühniana is identical with Spharotilus natans. A. Giard, Revue Internat. des Sciences, x. 190, in describing the infection of the drinking water of Lille, in 1882, by this Fungus, says that the "microgonidia," which are formed by transverse division of the clavate ends of the tubes, exhibit for some time an active movement, and with a bigh power (Hartnack, No. 12, immersion) he saw the flagellum. A full account of this Fungus will be found in Quart. Four. Micr. Sci., 1873, p. 163.TR.] 


\section{( 57$)$}

\section{CHAPTER II.}

\section{SACCHAROMYCETES.}

The Saccharomycetes, or Yeast Fungi, are unicellular plants, which multiply themselves by budding, and reproduce themselves by endogenous spores. They live singly or united in bud-colonies, chiefly in saccharine solutions, where they excite alcoholic fermentation.

In most of the Saccharomycetes the cells are round, oval, or elliptic; seldom are they elongated into cylindrical tubes, which are divided by transverse partitions, and may be regarded as the first indication of the formation of hyphæ, i.e. of a mycelium. For the purpose of multiplication the cell forms an outgrowth, which is filled with a portion of the contents of the mother-cell; gradually assumes the form and size of the latter, and separates itself from it by a wall. Both cells can in like manner produce fresh daughter-cells, which often remain for a considerable time united with one another, and on separation continue to grow independently.

The formation of spores succeeds most easily on a moist solid substratum. Typically the whole cell-contents divide themselves into $2-4$ roundish portions, or contract into a single spherical body. The portions of the contents 
surround themselves each with a membrane, and so produce the spores, which can bud like the vegetative cells.

To the Yeast Fungi (in the narrower sense) belongs the capacity of decomposing the sugar of a fluid into alcohol and carbonic acid, i.e. of exciting alcoholic fermentation.

The carbonic acid comes off in rapid streams of bubbles, while the alcohol, as well as certain subordinate constituents of sugar, remains behind.

The fermentation proceeds most energetically with restricted access of air ; but, if the air is excluded for a long time, the yeast cells perish.

The same is true of the Saccharomycetes, especially in a botanical aspect, as of the Schizomycetes. Just as in the latter case, so also in this, it is necessary to impose a limit upon the accepted species, and only those founded by trustworthy investigators can be considered. Of course there remain even then many doubtful points ; for the majority of the now accepted species of Saccharomycetes may be only various forms of one and the same species, which have become differentiated by changed conditions of growth.

XVII. SACCHAROMYCES, Meyen (in Wiegmann's Archiv, iv. vol. ii. p. I0o).

Unicellular Fungi, with vegetative increase by budding, and reproduction by spores, which, for the most part, arise by subdivision of the contents of the mother-cell.

A.-Species not producing a Mycelium.

8o. S. cerevisiæ, Meyen (l.c.).

Torula cerevisia, Turpin.

Cryptococcus fermentum, Kützing.

Cryptococcus cerevisia, Kützing. 
Hormiscium cerevisia, Bail.

[Saccharomyces minor, Engel ?]

Cells mostly round or oval, $8-9 \mu$ long, isolated or united in small colonies. Spore-forming cells isolated,

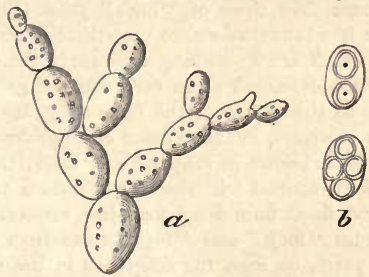

Fig. 58.-Saccharomyces cerevisia; $a$, a bud-colony;

b, two spore-forming cells (after Lürssen).

I I-I $4 \mu$ long; spores mostly three or four together in each mother-cell, 4-5 $\mu$ in diameter. (Fig. 58.)

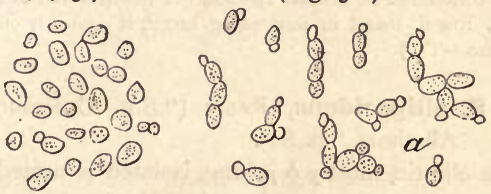

Fig. 59.- "Low yeast," Saccharomyces cercvisia ; $a$, the same, budding actively (after Pasteur).

In beer, in both high and low fermentation.

The true beer-ferment is found in the various sorts of
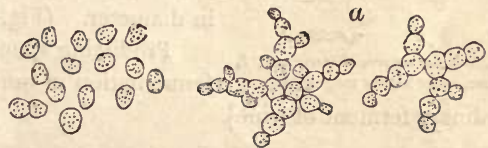

Fig. 60.- "High yeast," Saccharomyces cercvisia; $a$, the same, budding actively (after Pasteur).

beer, in both modes of fermentation; it is cultivated on a 


\section{Synopsis of the Bacteria and Yeast Fungi.}

large scale, and then yields the German yeast, a mass which consists of yeast-cells and water.

[There are two races of this species, "high" yeast and "low" yeast. The cells of "low" yeast (Fig. 59) are slightly smaller and more oval in shape than those of "high" yeast (Fig. 60), and in budding produce less ramifications, so that there is an absence of the globular clusters which are so striking a feature in the development of "high" yeast, when examined at an early stage of growth. "Low" yeast never rises to the surface of the fermenting fluid, which is thus left clear, but it produces, in the opinion of Englishmen at least, an inferior beer. This is known in England as "Bavarian" beer. With high yeast, the newly formed cells rise to the surface as the fermentation proceeds, and there form large foam-like masses. It is doubtful whether the names "high" and "low" arose from these different positions of the yeast, or from the difference in the temperatures at which they work. High yeast ferments at a temperature between $16^{\circ}$ C. and $20^{\circ} \mathrm{C}$., while low yeast is usually employed at a temperature of from $6^{\circ} \mathrm{C}$. to $8^{\circ} \mathrm{C}$., and rarely more than $10^{\circ} \mathrm{C}$. In Pasteur's (from a morphological point of view) confused "Études sur la Bière," these are considered as distinct species, but this position is untenable. S. minor, Engel, found in fermenting bread, is probably only a form of the same.-TR.]

81. S. ellipsoideus, Reess ("Bot. Untersuch. über Alkoholg.," p. 82).

Cells elliptic, mostly $6 \mu$ long, isolated or united in little

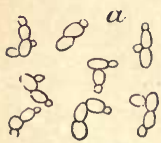

$\times 420$

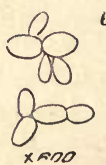

$\times$ ano b

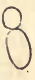
lated; spores $2-4$ together in each mother-cell, $3-3.5 \mu$ in diameter. (Fig. 6r.) Producing spontaneous fermentation in must; [this forming cells mostly iso-

Fig. 61.-a, Saccharomyces ellipsoideus; $b$, the same, more highly magnified. branched colunies. Sporeis the ordinary ferment of wine].

82. S. conglomeratus, Reess (l.c., p. 82).

Cells almost round, $5^{-6} \mu$ in diameter, united in clusters, 
which consist of the numerous cells produced by budding from one or a few mother-cells. Spore-forming cells often united in twos, or with a vegetative cell; spores 2-4 in each mother-cell. (Fig. 62b.)

In wine at the beginning of the fermentation, and on decaying grapes.
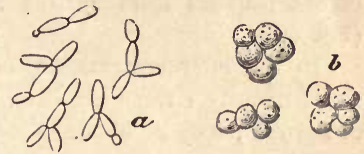

Fig. 62.-a, Saccharomyces exiguns; $b$, S. conglomeratus, $\times 600$.

83. S. exiguus, Reess (l.c., p. 83).

Cells conical or top-shaped, about $5 \mu$ long, reaching ${ }_{2} \cdot 5 \mu$ in thickness, united in sparingly branched colonies. Spore-forming cells isolated, each with $2-3$ spores, which lie in a row. (Fig. 62a.)

In the after-fermentation of beer.

84. S. Pastorianus, Reess (l.c., p. 83).

Cells roundish-oval or elongated-clavate, of varied size.

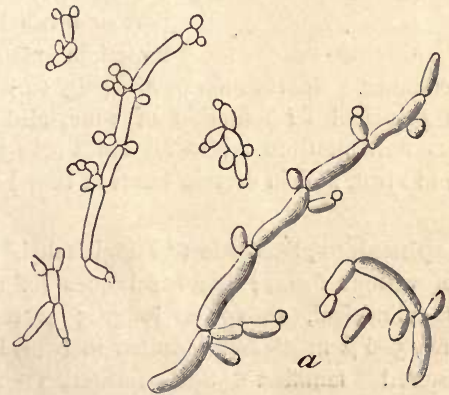

Fig. 63.-Saccharomyces Pastorianus; $a$, the same, more highly magnified (after Pasteur).

Colonies branched, consisting of primary clavate cells, $18-$ 
22. $\mu$ long, which produce secondary roundish or oval daughter-cells, 5-6 $\mu$ long. Spore-forming cells roundish or oval; spores from 2 to 4 together, $2 \mu$ in diameter. (Fig. 63.)

In the after-fermentation of wine, and fruit-wine, or spontaneously fermenting beer. [The "caseous ferment" of Pasteur; niay be obtained sometimes in English yeast.]

\section{S. apiculatus, Reess (l.c., p. 84).}

Carpozyma apiculatum, Engel.

Cells lemon-shaped, shortly apiculate at each end, 6-8 $\mu$ long, 2-3 $\mu$ broad, sometimes slightly elongated, and,

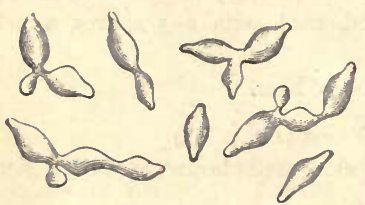

Fig. 64.-Saccharomyces apiculatus, $x$ about 500 . according to Hansen, towards the end of their growth becoming oval; daughter-cells arising only from the ends of the mother-cell ; for the most part soon isolated, rarely united in small, scarcely branched colonies. Spores unknown. (Fig. 64.)

In the principal fermentation of wine, and in other spontaneous fermentations. [On all kinds of fruit, stonefruits, etc., in must, and in certain kinds of beer.]

86. S. sphæricus, Saccardo ("Fungi Italici," fig. 76).

Cells of various forms; the basal ones (of a colony) oblong or cylindrical, IO-15 $\mu$ long, $5 \mu$ thick; the others round, $5^{-6 \mu} \mu$ in diameter, united in bent, branched, often clustered families. Spore-formation unknown. (Fig. 65.)

On the fermenting juice of Lycopersicum esculentum, the tomato. 


\section{Saccharomyces.}

[Saccardo, who regards this as a Hyphomycete of low organization, says ("Michelia," i. p. 90), "Occurring in minute, flatly convex, gregarious and confluent, dirty-white heaps; conidia perfectly spherical, $5^{-6} \mu$ in diameter, collected in variously curved, branched and often
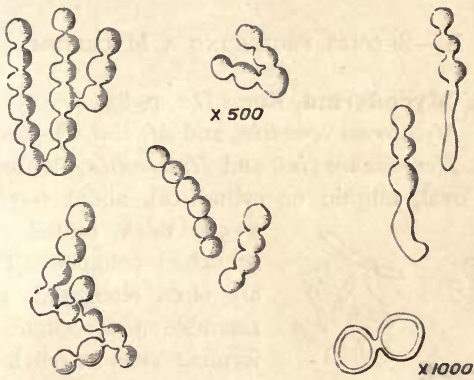

Fig. 65.-Saccharomyces spharicus (after Saccardo).

clustered chains, separating with difficulty, hyaline, usually supported on oblong or subcylindrical bases, $10-15 \mu \times 5 \mu$." There is a strong likeness between this and Hormiscium album, Bonorden, except in habitat.]

87. S. glutinis (Fresenius), Cohn ("Beiträge," i. p. 187).

Cryptococcus glutinis, Fresenius.

Cells round, oval, oblong, elliptic to shortly cylindrical, 5-II $\mu$ long, about $4 \mu$ broad, isolated or united in twos, seldom more together. Cellmembrane and contents colourless, when fresh; but, when moistened again after drying, with a faintly reddish central nucleus. Spore-formation unknown. (Fig. 66.)

On starch-paste, slices of potato, etc.,

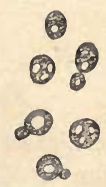
forming rose-coloured, slimy spots, which (after Cohn). have at first a diameter of $\frac{1}{2}-1$ millimetre, but by degrees 
64 Synopsis of the Bacteria and Yeast Fungi.

spread and become confluent in patches of as much as one centimetre broad.

The colouring matter is unchanged by acids and alkalies.

B.-Species producing a Mycelium.

88. S. Mycoderma, Reess (l.c., p. 83).

Mycoderma cerevisia, and $M$. vini, Desmazières.

Hormiscium vini, and $H$. cerevisia, Bonorden.

Cells oval, elliptic or cylindrical, about $6-7 \mu$ long,

a
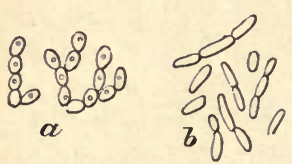

Fig. 67. Saccharomyces Mycoderma, budding ; $a$ is the Hormiscium vini of Bonorden; $b$, a more cylindrical form. 2-3 $\mu$ thick, united in richly branched colonies. The cells are often elongated, so as to resemble a mycelium. Sporeforming cells as much as $20 \mu$ long; spores $\mathrm{I}-4$ in each mothercell. (Figs. 67, 68.)

On fermented fluids, sauerkraut, juices of fruit, etc, forming on beer and wine the so-called "mould."

This and the following species reach in their development

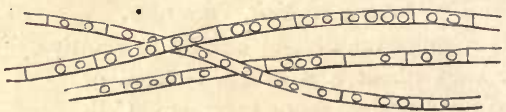

Fig. 68.-Saccharomyces Mycoderma, from home-made " ginger-beer," with spores, $\times 500$.

the highest rank among the Saccharomycetes. The cells often form, especially in watery fluids, long tubes, which are divided by transverse partitions, and fall into single pieces at those points. These bud, in their turn, in the same manner. 
While the true Yeast Fungi grow submerged in the higher layers of the fluid, and there excite active alcoholic fermentation, the "mould" grows on the surface, without exciting fermentation. When artificially forced to grow submerged, of course a little alcohol is produced, but the Fungus soon perishes.

Although the growth of the layer of "mould" goes hand-in-hand with the souring of the wine or beer, yet the Saccharomyces is not the cause of the latter. The formation of vinegar from alcohol is produced rather by other Fungi, whose systematic position is still undetermined. According to some, it is a species of Vibrio (Spirillum) which causes this decomposition.

89. S. albicans (Robin), Reess.

Oidium albicans, Robin.

Cells partly round, partly oval, oblong or cylindrical, $3.5-$ $5 \mu$ thick; the round ones 4 $\mu$ in diameter, the cylindrical ones ro to 20 times as long as thick. Bud-colonies mostly consisting of rows of cylindrical cells, from the ends of which spring rows of oval or round cells. Spores formed singly in roundish cells. (Fig. 69.)

On the mucous membrane of the mouth, especially of in-

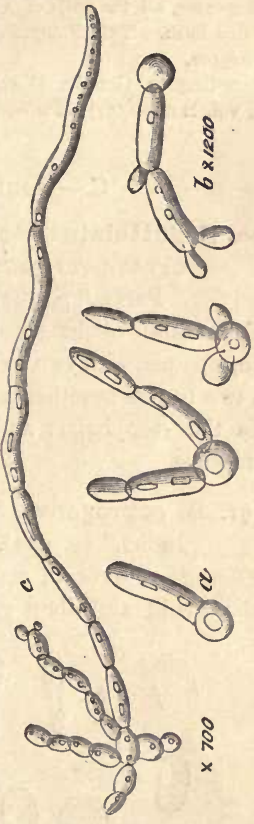
fants, forming the disease known as aphtha, or thrush. Also in animals.

This Fungus appears in the form of larger or smaller greyish-white heaps, which nevertheless do not consist exclusively of the Saccharo- 
myces, but also contain Schizomycetes and the mycelia of moulds. When cultivated, the Fungus forms long-jointed, richly branched threads; at the upper end of each articulation there is usually a crown or bundle of shorter cells, which are oval or round in form, and bud in their turn. In other cases, all the cells of a bud-colony remain short, and assume a rounded form. This Fungus excites alcoholic fermentation only in a small degree.

According to Grawitz (Virchow's Archiv für Path. Anat. und Phys., vol. lxx. p. 557), S. albicizns is identical with S. Mycoderma.

\section{C.-Doubtful Species.}

90. S. guttulatus (Robin).

Cryptococcus guttulatus, Robin ("Hist. Nat. Vég. Paras.," p. 327).

Cells elliptic or elongated-ovate, r $^{-24} \mu$ long, $5-8 \mu$ thick, brown, opaque, with two to four colourless drops, isolated or from two to five together. Spore-formation unknown.

In the œsophagus and intestines of mammals, birds, and reptiles.

[91. S. coprogenus, Saccardo et Speggazini ("Fungi Italici," fig. 9I I).

Effused, superficial, rather compact, dirty-rose colour ; conidia ovoid and then globose, I2-I4 $\mu$ long, IO-I I $\mu$
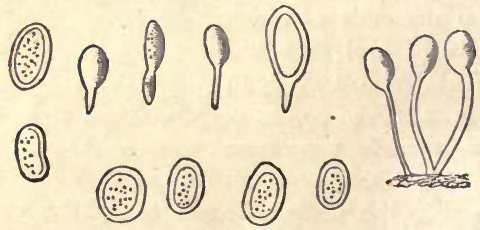

Fig. 70.-Saccharomyces coprogenws, $\times 500$ (after Saccardo).

broad, forming very short chains or solitary, often provided with a tail-like appendage (? from germination), clouded 
within, when in clusters pale rose-coloured, hyaline ("Michelia," ii. p. 287). (Fig. 70.)

On fermenting human ordure, where it forms a somewhat waxy layer, almost like a Corticium. This also is considered by Saccardo to be a Hyphomycete.]

[92. S. olei, Van Tieghem (Bull. Soc. Bot. France, vol. xxviii).

Cells oval, arranged in branching threads, $4 \mu$ long, $2 \cdot 5$ $\boldsymbol{\mu}$ broad ; cell-contents pale rose-colour.

In olive oil. The oil is changed in appearance by the growth of this Fungus, becoming white and milky from saponification. No gas is disengaged during growth, nor is any special odour perceptible. The ordinary Saccharomycetes will not grow in oil.]

[Dr. Klein, Quart. Four. Micr. Sci., 1883, p. 268, describes a pink "Torula," consisting of cells $9-10 \mu$ in diameter, which he assumes to be those of S. cerevisie. It formed pink droplets on a nutrient fluid; the colour was only developed on the free surface, and not in the submerged growth.

What is called the "gingerbeer" plant, used in country districts to produce home-made ginger-beer, consists of "low" or sedimentary yeast, and S. Mycoder. $m a$, together with various species of Bacillus, probably $B$. Ulina and $B$. subtilis, and in addition the "Mucor-ferment" of Pasteur (Fig. 7 $\mathrm{I}$ ), which is considered by

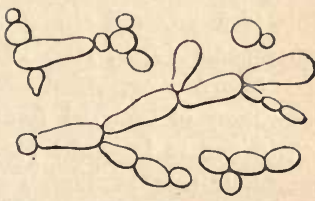

Fig. 71. - Mucor-ferment of Pasteur (Mucor racemosus), from ginger-beer. him to be a submerged vegetating form of Mucor racemosus. - TR.] 


\section{(68)}

\section{CHAPTER III.}

CLASSIFICATION.

THE classification of the Schizomycetes is at present in a remarkable transition state. That presented in the foregoing pages, Chapter I., is due in the main to Cohn, and has been supported by Koch, Van Tieghem, and others. It is founded upon the idea, which would obviously occur first to an observer, that all the various morphologically or physiologically distinct forms belong to different species. This idea received strong apparent support from Koch's experiments (Vour. Roy. Micr. Soc., 1881, pp. 950-952, and Quart. Jour. Micr. Sci., 1881, pp. 65I-654) in the cultivation of bacterial forms upon gelatine of sufficient consistence to keep the progeny of any one germ in its immediate neighbourhood, and thus prevent that mixture of diverse forms which has been so often perplexing. Under these conditions, according to Koch, Micrococcus produced nothing but Micrococcus, Bacterium nothing but Bacterium.

In opposition to this theory, Nägeli, Billroth, Hallier, Hoffmann, Lüders, Cienkowski, Neelsen, Zopf, Haberkorn, and others maintain that in most cases a Schizomycete passes through a series of adaptive forms-that a Micro- 


\section{Classification of the Schizomycetes.}

coccus may become a Bacterium, a Bacterium a Bacillus, a Leptothrix, or even a Spirillum and a Spirochæta. Ray Lankester (Quart. Jour. Micr. Sci., xiii., 1873, p. 408) and Lister were the first to promulgate this opinion in England; but the truth of the former's observations, on Bacterium rubescens, has been partially denied by several observers, and is not yet entirely free from doubt.

The first classification of the Schizomycetes was that due to Ehrenberg, in 1838 ("Die Infusionsthierchen," p. 75), of which the following is the essential part:-

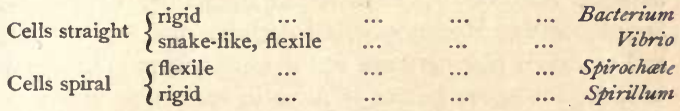

It may be noted that Vibrio is here conceived to be naturally straight-lined, but capable of bending in undulations of a serpentine form, being thus distinguished from Spirillum by the fact that the undulations lie all in one plane. But most modern observers are agreed that the species referred to Vibrio belong to two classes-the one, in which the undulations are serpentine, being merely Bacillus; the other, in which they are spiral, being undistinguishable from Spirillum. This is, therefore, another reason, added to those which Dr. Winter has given (supra, p. 46), why the name Vibrio should be dropped.

Cohn's first classification $(1872)$ is merely a modification of Ehrenberg's.

A. Cells at times united in gelatinous families.

a. Cells round, Sphærobacteria

... Micrococcus

b. Cells oblong, Microbacteria ...

... Bacterium

B. Cells never united in gelatinous families.

a. Cells thread-like, Desmobacteria.

1. Threads straight

2. Threads undulated

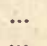

$\cdots \quad \cdots$

Bacillus Vibrio 


\section{Synopsis of the Bacteria and Yeast Fungi.}

b. Cells spiral, Spirobacteria.

I. Spirals flexile ...

$\begin{array}{llll}\cdots & \cdots & \ldots & \text { Spirochate }\end{array}$

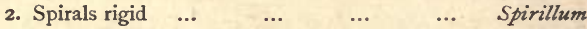

The division into sections $\mathrm{A}$ and $\mathrm{B}$ is founded upon a mistake, since some of the forms in the latter are now known to occur in a zooglœa. The Vibrio here mentioned is distinct from Ehrenberg's Vibrio, and included only $V$. Rugula and $V$. serpens.

This classification Cohn revised in 1875 (see Quart. Jour. Micr. Sci., 1876, pp. 259-278), adding the genera Sarcina, Ascococcus, Leptothrix, Beggiatoa, Crenothrix, Streptococcus, Myconostoc, Cladothrix, and Streptothrix, and moreover placing these and the old genera in company with the analogous genera of Algæ in one series, as Schizophytæ. But these changes attracted but little notice except among specialists, and the arrangement given above, with a few additions, is that familiar to the majority of the students of Bacteria.

The growth of views inconsistent with this classification will be seen by the following resumé of a few of the contrary opinions. The earlier observers, whose opinions were based on insufficient grounds, may be disregarded.

J. Lister (Quart. Jour. Micr. Sci., 1873, pp. 380-408, pl. 19-2I) gave an account of several experiments with Bacteria, in which great precaution was taken to ensure accuracy, and in one case, of a Bacterium which appeared spontaneously in milk, he observed coccus, bacterioid, bacillar, and leptothrix forms, and recognised their genetic connection.

Ray Lankester's investigation of Bacterium rubescens (1873) has been already noticed. Few even of succeeding writers have gone further in uniting different and apparently distinct forms. See. also his further observations in the same journal (1876, pp. $278-283$ ), and infra, p. 85 . 


\section{Classification of the Schizomycetes.}

Geddes and Ewart (Proc. Roy. Soc., xxvii., 1878, p. 481) confirm Lankester's results in the main. J. C. Ewart (Quart. Jour. Micr. Sci., 1878, p. 16r), after investigating Bacillus anthracis, advocates the doctrine that Micrococcus, Bacterium, and Bacillus are only phases of the same lifehistory, "which," he says, "is doubtless common to all Bacteria."

Cienkowski ("Zur Morphologie der Bacterien," I 878) held (I) that the zooglœa form is analogous to the Palmella form of chlorophyllose Algæ; (2) that Crenothrix, Leptothrix, and Cladothrix give rise to the zooglœa forms of Bacteria, e.g. of B. Termo and B. Lineola; (3) that Bacteria are transformed into Micrococci by subdivision, and into Leptothrix by continued growth; (4) that Micrococcus, Bacterium, and the so-called Torula forms are not genetically distinct.

W. Zopf ("Ueber den genetischen Zusammenhang von Spaltpilz-formen," r88r) not only confirmed the views which Cienkowski had previously expressed of the genetic connection of Micrococcus, Bacillus, and Leptothrix, but also asserted that Vibrio, Spirillum, Spirochæta, and Ophidomonas can enter into the same life-cycle with these. $\mathrm{He}$ investigated chiefly Cladothrix, Beggiatoa, and Crenothrix. But he allows that not all the Spaltpilze have this pleomorphism, so that it is quite possible that some of them occur under one form only.

C. von Nägeli ("Untersuch. über niedere Pilze" (I882), i. pp. 129-139) maintained that all known forms of Schizomycetes are connected by intermediate links, and that any division into species, however convenient for the purposes of description, has no scientific value. He considers that the same species can occur in widely different forms, according to the circumstances of its nutrition. 


\section{Synopsis of the Bacteria and Yeast Fungi.}

J. Haberkorn (Botan. Centralblatt, x., 1882, p. I00) puts forward the opinion that all Cohn's four tribes are forms of a single large genus with numerous species, which show alternations of generations and pleomorphy.

W. Zopf ("Zur Morphologie der Spaltpflanzen," 1882) adduced further evidence to prove the truth of the view that all the genera of the Schizomycetes described by Cohn and others, are simply stages of development dependent upon nutrition.

W. Miller (Archiv für exp. Pathol. und Pharmak., xvi., 1882, p. 296) states that he observed transitional forms between Leptothrix buccalis and other genera, viz. coccus, bacillus, and spiral forms; and again (Berichte Deutsch. Bot. Gesell., i., 1883, pp. $22 \mathrm{I}-224$ ) he traced the growth of a Leptothrix from the teeth of a dog into forms more or less resembling Bacterium, Micrococcus, Spirillum, and Spirochæta.

H. Kurth (Berichte Deutsch. Bot. Gesell., i., 1883, pp. 97-99) not only traced the growth of his Bacterium Zopfii from leptothrix into rod and coccus forms, but also determined the conditions under which one or the other is produced-the rods being the vegetative and the coccus the resting stage.

H. Zukal (Österr. Bot. Zeitschrift, xxxiii., 1883, p. 73) connects Bacillus subtilis, not only with Leptothrix parasitica, but also with the Algæ L. muralis and Drilosiphon Julianus, Zuk. These observations seem to be founded upon errors.

E. Klein (Quart. Jour. Micr. Sci., 1883, p. 260) describes a torula-like variety of Bacillus anthracis, which passed, sometimes even upon the same filament, into the typical Bacillus. Similar forms of Bacteria have been described by many others. Klein's growth, however, judging from his figures, does not resemble a true Saccharo- 
myces. The word "Torula," like "Vibrio," is very much misused by non-botanists. The true Torula belongs to the Hyphomycetes.

F. Neelsen ("Neuere Ansichten über die Systematik der Spaltpilze," Biolog. Centralblatt, iii., r $88_{3}$, p. 545) gives a review of the present state of the question, and confirms Zopf's conclusions.

The most exhaustive account of the new views is contained in Zopf's "Spaltpilze," in Schenk's "Encyclopädie der Naturwissenschaften," r883. We will first give a condensed account of his previous observations. Taking first Cladothrix dichotoma, he found that the pseudo-dichotomous threads resolve themselves by transverse division into short cylindrical cells, which round themselves off by degrees and then represent Micrococci. These Zopf compares to gonidia. From these, after separation, short rods (Bacteria) are evolved, which again, by continuous growth in length and the formation of transverse septa, produce Bacilluslike threads, which ultimately resemble Leptothrix parasitica, Kützing. These threads, like the Cladothrix, are surrounded by a delicate gelatinous sheath which takes up iron compounds from the water in which it lives, and thus puts on the appearance of $L$. ochracea, Kützing. From this the typical Cladothrix is produced again by false branching. Moreover, small fragments break off and swim about, and, under certain circumstances, bend into a spiral ; these spiral forms are always articulated, and their elements are either rod or coccus like. The height and breadth of the spirals are very variable, as well as the thickness of the threads, and some forms resemble Vibrio, others Spirillum and Spirochæta. The zoogloa form, of even more than one kind, is also met with in Cladothrix.

Zopf also investigated Beggiatoa alba, Vaucher, which, 


\section{Synopsis of the Bacteria and Yeast Fungi.}

in its Leptothrix form, after reaching a certain length, shows a slow oscillating movement. At the ends of the threads Micrococci arise, which unite in a zooglœa and also grow into rods; pieces of the end of the Beggiatoa grow crooked, fall off, and form Spirillum-like fragments, which swim about by means of flagella.

Again, Beggiatoa rosea-persicina, Zopf (Cohnia rosea-persicina, Winter), also forms Micrococci; these cocci are of two sizes, which grow genetically one from the other. From the cocci grow threads of very varied lengths. Similar results obtain in Crenothrix.

These three genera, Cladothrix, Beggiatoa, and Crenothrix, with Leptothrix, form the highest developments of the Schizomycetes; in them a distinction can be made out between base and apex. The mode of vegetative multiplication in this class of Fungi is always by bipartition (from which circumstance, indeed, the name is derived); this bipartition usually takes place in one direction, but occasionally in two or even three. The cells are always enclosed in a cell-wall; this wall is usually composed of cellulose, but in a certain group, viz. the putrefactive Bacteria, it consists of a substance not much different from the cellcontents, to which the name of mycoprotein has been given. This shows a deviation from the vegetable cell in the direction of the animal cell, and accounts for the discrepancies between earlier observers, some of whom, e.g. Dr. Letzerich, always succeeded in obtaining the ordinary cellulose reaction (a blue coloration with iodine and sulphuric acid), while others always failed. All the genera, except the filiform ones, may be provided with flagella. The reproduction by spores has been observed, not only in Bacillus, but also in other forms, e.g. by Van Tieghem in Leuconostoc, Spirillum, Spirochæta, and Bacterium. There 
is mostly only one spore in each cell. The zooglœa forms are produced by aggregation, combined with the same tendency of the cell-walls to gelatinise which is found in many of the lower Algæ.

As the result of his observations, Zopf proposes the following classification :-

I. COCCACEA. Possessing only the (micro-)coccus form, and the thread form which arises from the juxtaposition of the cocci in $\begin{array}{llllllll}\text { a line } & \ldots & \ldots & \ldots & \ldots & \ldots & \text { Leuconostoc }\end{array}$

II. Bacteriacee. Possessing four forms, cocci, bacteria (short rods), bacilli (long rods), and leptothrix threads. The last show no distinction between base and apex. No spirals

Bacterium, Clostridium

III. Leptotriche£. Possessing five forms, cocci, bacteria, bacilli, leptothrix (which last shows a distinction between base and apex), and spiral forms

Leptothrix, Beggiatoa, Crenothrix, Phragmidiothrix

IV. Cladotrichee. Possessing coccus, rod, thread, and spiral forms. Threads provided with false branching (pseudo-dichotomy)

There is one more development of opinion with respect to the Schizomycetes of which mention must now be made. The belief is gaining ground that, among the lowest forms of vegetal life, no such sharp distinction as hitherto can be drawn between those which contain chlorophyll (the algal series) and those which do not (the fungal series). This view, which is embodied in the classification adopted by Sachs in the later editions of his text-book of Botany, is approved by Cohn (see Quart. Jour. Micr. Sci., 1876, pp. 275, 276), and is now supported by Zopf himself. According to the latter, such Algæ as Glaucothrix and Gliothrix, etc., show Chroococcus-like stages of development which answer to the Micrococcus stage among the Schizomycetes. The tendency of both to aggregate in gelatinous colonies has been already adverted to. More- 


\section{Synopsis of the Bacteria and Yeast Fungi.}

over, Van Tieghem and Engelmann describe (see infra, p. 88) bacterioid forms containing chlorophyll, and the resemblance between Beggiatoa and Oscillaria, both in form and in the characteristic oscillating movement, is so great that some botanists do not yet separate them. Again, Leuconostoc differs from Nostoc solely in the want of chlorophyll, the very peculiar formation of the spores being alike in both. Compare also Cohnia with Clathrocystis. The two kinds evidently form two parallel series, which may conveniently be united under the name of Schizophyta, being called Schizophyceæ and Schizomycetes respectively. They are, nevertheless, physiologically so distinct that there are decided objections to interweaving them in one series, as Cohn proposed. It would seem to be proved that, in all cases where oxygen is given off during vegetable growth, chlorophyll is present; Rostafinski at one time believed that Hæmatococcus dissociated carbonic anhydride without chlorophyll, but it is now known to be present in that Alga, though masked by the red colouring matter.

There may, perhaps, be detected, in the recent spread of Zopf's views upon the pleomorphy of the Bacteria, a little of that rage for "following the fashion," which is almost as rife among scientific men as in the outer world. A review of what has taken place in similar cases before will teach the necessity of caution. When the swarm-spores of Algæ were first discovered, it was prophesied by Siebold that most of the green moving Infusoria, described by Ehrenberg, would be found to be only similar stages of other algal forms. But this prophecy has not been fulfilled. Again, when the doctrine of the pleomorphy of the Mucorini was first started by De Bary, it was eagerly seized upon and its scope rapidly extended by rash observers, until in the writings of some authors there was a confusion of species 


\section{Classification of the Schizomycetes.}

almost incredible. One writer, Carnoy, even carried the doctrine to the only rational conclusion which could be deduced from such kind of observations as then existed: he asserted that every species of Fungus, cultivated under suitable conditions, could be transformed into Penicillium! But later investigators, e.g. Van Tieghem, throw grave doubts upon the accuracy of even De Bary's observations, and he himself ("Beiträge," iv. r) seems to admit that he was mistaken.

There are, however, many cases of pleomorphy in Fungi, which may be considered as proven. We have only to refer to the recent victorious establishment of the pleomorphism of the Uredines, and it is natural to expect that similar cases exist in other groups. But here we may learn another lesson. Not every Puccinia passes through the three stages which are typical of a Uredinous fungus; some occur in one form alone, so far as our present knowledge goes. The same may be expected to be the case with the Schizomycetes. Even if we grant that some of them do pass through a number of different forms, which have been hitherto described as genera, it need not be inferred that there are no distinct Micrococci, no independent Spirilla. In fact, as evolutionists, considering that we are here dealing with the simplest forms of life, we might anticipate that many of the species would remain permanently, by arrest, in forms which are mere stages of development of those more highly evolved. Moreover, though one stage of Cladothrix dichotoma may resemble Bacterium Termo in outward form, as Zopf asserts, it by no means necessarily follows that they are identical. There may be differences between them of which we have as yet no cognisance, for little is known of the internal constitution of the Bacteria. What is wanted now is a thorough and searching investigation of all 
the so-called species, in various media and under varying circumstances, with the aid of all the modern refinements for keeping the cultivations pure.

There is still another speculation to which the facts appear to lead the way. A species such as those investigated by Zopf is called a "Protean" species, and the various forms are considered to be a series of adaptations to the environment. Nägeli, as we have seen, carried the theory so far as to assert that there are no real species among the Schizomycetes; and Buchner considered that he had transformed the harmless Bacillus subtilis by cultivation into the virulent $B$. anthracis, although his conclusions are controverted by Cohn, Klein, and others. Much of the disputation on this topic of "species" arises from the fact that many persons cannot readily conceive a species in the new light which the Darwinian theory has thrown upon it. There can be no doubt that new species not only may, but actually must, be making at the present moment. It is not generally recognised that, to our floriculturists, the making of what would, if spontaneous, be universally considered a new species has been a frequent occurrence. Not only is it probable that $B$. anthracis was developed from $B$. subtilis (whether Buchner's conclusions be true or false), but man, by a change of environment if continued long enough, may at any time produce a similar change in another species. During the siege of Paris, small-pox continued its ravages, gradually assuming a more virulent and malignant form; the cause of this can only be that the micro-organism of small-pox was changing its physiological nature, and, had the conditions been constant for a sufficient length of time, it might ultimately have formed what would be to all intents and purposes a new species. Pasteur's "cultivation" of disease-germs in order to reduce their virulence 
is only an application of the same principle in the opposite direction.

It follows (I) that we must consider as a species any form or group of forms which, under present conditions, can be clearly distinguished from all other forms, even though we may know that, if the environment were changed, the species would change too; and (2) that species must necessarily be of various ranks and of various degrees of definiteness, as indeed we know to be the case. And in no part of the scale of organised beings should we expect to find clearer proof and more frequent examples of this doctrine than among the lower Algæ and their derivatives, the lower Fungi.

In conclusion, it may be remarked that neither Cohn nor Zopf have put forward their rival systems as final. At the time of its promulgation Cohn's first arrangement was indeed the only possible one, but he never asserted that all the forms which he catalogued would be found to be true and independent species. Zopf, on the other hand, does no more than devise a system in which certain newly discovered facts may find adequate representation; but he does not pretend that it will include all Schizomycetes. The ultimate classification will probably be a compromise between the two, though the exact form which it will assume it is at present impossible to foresee.

The classification of the Saccharomycetes is in as undecided a state as that of the Schizomycetes, but in a somewhat different way. In this case also there are the two opposing parties-one holding that most of the forms which have been described in Chapter II. are independent species; the other, that they are for the most part only phases of growth of one or a few species; but the third view, which 


\section{Synopsis of the Bacteria and Yeast Fungi.}

in the case of the Schizomycetes has attracted but little notice, viz. that they are not autonomous Fungi at all, but merely stages of development of species belonging to other classes, finds here a numerous and active following.

Max Reess ("Zur Naturgeschichte der Bierhefe," I868, and "Botanische Untersuchungen über die Alkoholgährungspilze," I 870) is one of the most conspicuous upholders of the first doctrine, and his opinions are adopted by Dr. Winter. Hallier and Hoffmann had previously put forward the same doctrine of pleomorphism with regard to the Saccharomycetes which they held for the Schizomycetes; and the latter, in a treatise, "Ueber Bacterien," in the Botanische Zeitung (1869, p. 305), maintained, as so many others have done, that the Yeast Fungi are derived from the Moulds; Penicillium and Mucor Mucedo were the most generally credited with being the source from which they originated. Many other Fungi are now known to have stages of growth in which they simulate the Saccharomycetes. Quite recently, however ("Botanische Untersuchungen," heft v., r883), Oscar Brefeld has elaborated a comparatively new line of investigation in this respect, and, as no account of his researches has to my knowledge appeared in an English dress, they may be shortly abstracted here. It must be premised that it is impossible to feel much confidence in the results at which he arrives, as he can be convicted of gross carelessness in many parts of his previous work, and the present long and tedious treatise is filled ad nauseam with peevish contentious disputations against De Bary and Van Tieghem and all others who differ from his opinions.

Brefeld considers that the conidia of various species of Ustilagineæ exactly resemble in mode of growth many of the forms of the so-called Saccharomyces. It is well known 


\section{Classification of the Saccharomycetes.}

that the spores of the Smuts, in germinating, protrude a thread from which spring tufts or clusters of sporidia ; these unite with one another by short transverse processes, and then give rise to sporidia or conidia of the third generation, and these to even a fourth kind. Brefeld's theory is that these successive generations of conidia do not merely resemble Saccharomycetes, but are identical with them. He cultivated the spores of many Ustilagineæ in nutrient fluids, and found that the conidia to which they gave rise were in form and dimensions similar to those of the various Yeast Fungi-those of Ustilago antherarum being ovate ; of $U$. Carbo, oblong-ovate; of $U$. maydis, fusiform; of $U$. betonice, cylindrical ; of $U$. Kühniana, small and roundish; of $U$.cruenta, filiform ; and so on. Moreover, he cultivated these sporidia in suitable media for numerous generations, and found that they reproduced themselves, so long as the conditions remained unaltered, with unfailing certainty the whole year through. A pair of Smut spores was induced to germinate, and the conidia which they produced were transported, with due precautions, into a drop of nutrient fluid, in which they continued to bud till the nutriment was exhausted. A few of these were then removed to another drop of the same fluid, and the process was continued for nearly thirty times, extending over a space of twelve months. The author considers that he has thus proved that these conidia can propagate themselves indefinitely by budding, just like the cells of Saccharomyces, and he asks, "If we had commenced this series of cultivations, not with the Smut spores, but with the conidia which arise from them, should we have been able to distinguish their mode of growth from that of the yeast of beer?"

As to the other morphological character of the Saccharomycetes, the endogenous formation of the spores, Brefeld 


\section{Synopsis of the Bacteria and Yeast Fungi.}

considers truly enough, that this is more closely related to the formation of spores in the sporangia of Thamnidium, Chætocladium, and Choanephora, than in the asci of the Ascomycetes, and that it is exactly paralleled by the formation of zoospores in the conidia of some species of Peronospora and Cystopus, and that similar phenomena are met with in the Gymnoasci.

With respect to the physiological character of exciting alcoholic fermentation, Brefeld says very little, but since the Mucor-ferment as well as other Fungi is said to possess the same property, it would seem, if all these considerations prove to be true, that the Saccharomycetes will have small claim to autonomous rank. To what species, however, if any, they must severally be attached, as budding conidia, remains to be determined. For the present, all this is mere speculation, and the only philosophic course is to treat them as independent Fungi, until the contrary is fully demonstrated. The authors who jumble up together Micrococcus, Mucor, Ustilago, Penicillium, Aspergillus, Oidium, Torula, and Saccharomyces are not the true friends of scientific progress. 


\section{( 83$)$}

\section{CHAPTER IV.}

\section{PROTEAN AND LITTLE-KNOWN SPECIES.}

THE present chapter will include those described Schizomycetes which are inadequately known, or the true bacterial nature of which is undecided, together with those Zopfian species which could not be placed in the Cohnian classification.

\section{BACTERIUM.}

93. B. Zopfii, Kurth (Ber. Deutsch. Bot. Gesell., i., I883, pp. 97-99, pl. iii.).

Observed in three forms, long leptothrix threads, rods, and cocci. In the fluid nutrient material at $20^{\circ} \mathrm{C}$. the rods passed into a swarming stage, and at $35^{\circ} \mathrm{C}$. the swarming motion ceased, and short oscillating threads were formed. When the nutrient material was nearly exhausted, the threads broke up into rods, and when it was quite exhausted, each rod divided into two cocci, which for the most part remained united in a figure of eight. When placed in fresh nutrient material, the cocci grew again into rods. Division of the cocci was never observed; they were round or slightly oval, and $\mathrm{I}-\mathrm{I} \cdot 25 \mu$ in diameter.

In the vermiform appendage of two hens which had died of an epidemic disease. The threads were distinguished by 
84 Synopsis of the Bacteria and Yeast Fungi.

their unusual length, forming long windings, and occasionally close coils. It is interesting to observe that the stages of development appeared to depend upon the quantitative composition of the nutrient fluid, and that the rods were the vegetative and the cocci the resting form. (Fig. 72.)

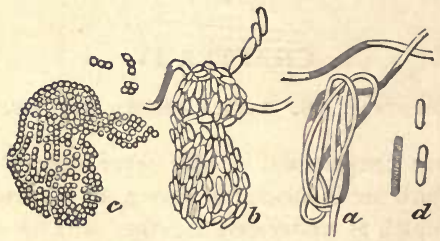

Fig. 72.-Bacterium Zopfii. a, a coil of leptothrix threads; $b$, the same coil, nine hours later; $c$, the same, thirty-seven hours later than $b ; d$, short rods, showing articulations, $\times 740$ (after Kurth).

94. B. merismopedioides, Zopf (Sitz.-Bericht. Bot. Ver. Provinz Brandenburg, and "Die Spaltpilze," p. 56).

This species forms threads of $\mathrm{I}^{-1}{ }^{\cdot} 5 \mu$ in thickness. These subdivide into long rods, then into short ones, and finally into cocci, which have the same diameter as the

- $8 \not B \& 8$

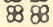

Fig. 73.-Bacterium merismopedioides (after Zopf). threads. The cocci pass through a motile stage, and then subdivide, at first in one direction, and then in two, thus forming the characteristic unilamellar plates, which resemble Merismopedia. These colonies may increase till they consist of $64 \times 64$ cells or more, which finally form a zooglœa. The cocci develop again into threads. (Fig. 73.)

In water containing putrefying substances. 
95. B. aceti (Kützing), Zopf.

Possesses (I) coccus forms, (2) short rods, (3) long rods, (4) leptothrix threads; all four can form a zooglowa, the two first also form swarms. It is characteristic that the longer rods and threads are not always cylindrical, but often provided with irregular swellings. Such forms have a rather thickened membrane, and a grey colour. (Fig. 74.)
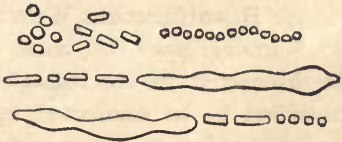

Fig. 74.-Bacterium aceti (after Zopf).

Has the power of oxidising alcohol into acetic acid.

96. B. rubescens, Lankester (Quart. Jour. Micr. Sci., I873, p. 408, pl. 22, 23).

Includes a series of forms, motile and immotile, which resemble one another in the possession of a common peach-coloured colouring matter, "bacterio-purpurin," which sometimes becomes reddish-brown. The author observed coccus, bacterioid, bacillar, acicular, and spiral forms, in various modes of combination.

In a fresh-water aquarium in which crayfish (Astacus) were decaying.

Cohn considers that Monas Okenii (q.v.), which is the form represented by Lankester (l.c., pl. 23, figs. 12, 20), does not belong to this life-cycle, and that the other forms belong to Cohnia roseo-persicina; this is now named by Zopf Beggiatoa roseo-persicina, because it possesses a Beggiatoa phase, which is mentioned by Lankester himself in his second article (l.c., I876, p. 283). Archer also unwittingly records the Reggiatoa phase in the same journal. Geddes and Ewart describe ("On the Life-History of Spirillum," Proc. Roy. Soc., xxvii., 1878, p. 48I) a madder-brown growth, which is evidently identical with Lankester's, and in which they have observed and figured the Beggiatoa phase, without perceiving its true significance, and mistaking also the sulphur granules for "spores." Mixed with this was a Spirillum, 
probably belonging to the same life-cycle, in which true spores were produced; the germination of these, which they observed, took place by the emission of a short curved tube, giving the spore a "comma"-like appearance; the tube soon became spiral. (See Spirillum rosaceum, Klein, p. 94.)

97. B. sulfuratum, Warming (l.c., p. 6 of the Resumé). Warming gives this name to a series of forms which he discovered on the coasts of Denmark, all of which he considers to be connected by intermediate stages. $\mathrm{He}$ includes under it Monas vinosa, Ehrenberg, $M$. erubescens, Ehrenberg, M. Warmingii, Cohn, and Rhabdomonas rosea, Cohn, as well as spiral forms. His $M$. gracilis, moreover, seems to differ merely in being more slender than Rhabdomonas, and was met with only in fresh water. All these are of a pale pink colour, and contain numerous sulphur granules. It appears to be distinct from $B$. rubescens, Lankester, in all its varieties.

98. B. lactis, Lister (Quart. Jour. Micr. Sci., r873, pp. $380-408)$.

Includes coccus, bacterioid, bacillar, leptothrix, and saccharomycetoid forms, motile and immotile, which the

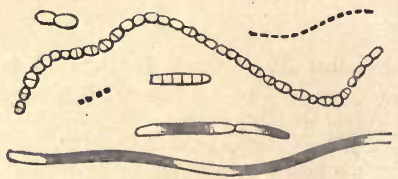

Fig. 75.-Bacterium lactis, $\times 1140$ (after Lister).

author obtained by pure cultivation of the Bacterium that appeared spontaneously in milk kept in a dairy. The long rods appear to be formed by segmentation of the leptothrix threads, these subdivide into short rods, and these into 
cocci; the cocci can grow again into threads. The cocci are about $5 \mu$ in diameter, mostly in pairs or fours, or in chains; the rods and threads $\mathrm{I} \cdot 25 \mu$ in diameter. (Fig. 75.)

Producing the lactic acid fermentation in boiled milk. Resembles Bacillus subtilis, (?) identical. This is interesting, as being one of the earliest observations of pleomorphism in the Schizomycetes.

99. B. fœtidum, Thin (Proc. Roy. Soc., xxx., I880, p. $473, \mathrm{pl} .6)$.

Occurred as Micrococci, singly or in pairs, $\mathrm{I}_{2} \cdot 2-\mathrm{I} \cdot 4 \mu$ in diameter. On cultivating them, with proper precautions, he found also short and long rods, and leptothrix threads, and all the stages of transition between these and the Micrococci. In the rods, oval spores about $\mathrm{I}^{\cdot} 5 \mu$ long were

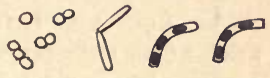

Fig. 76.-Bacterium fatidum, $\times 900$ after Thin). formed, one at each extremity of a cell, as in Bacillus. (Fig. 76.)

In the alkaline serous exudation from the soles of the feet of a person who suffered from profuse sweating of the feet, producing a fotid odour, also observable in the cultivations, in which, however, it became gradually weaker.

roo. B. decalvans, Thin (Proc. Roy. Soc., xxxiii. p. 247 , pl. 3).

Occurred as minute bodies, highly refractive, of a definite size and fixed shape, about $I^{\circ} 6 \mu$ long, usually in pairs. They became more numerous as the hairs became worse affected by the disease. (Fig. 77.)

In and on the roots of the hairs in Alopecia areata. Dr. Thin supposes that they

Fig. 77.-Bacterium decalvans, $\times 600$ (after Thin). penetrate downwards between the root-sheath and the hair, 
then penetrate the cuticle of the hair, and finally ascend within its substance, causing it soon to fall off.

ıо1. B. lucens, Van Tieghem (Bull. Soc. Bot. France, r879, p. r4r).

Motionless, remarkable for its strong refringence and brilliancy. Each cell forms a spherical spore.

On the surface of water containing other organisms.

102. B. photometricum, Engelmann (Revue Internat. Sci., ix., I 882, p. 469).

Cells of a slightly reddish colour; the author describes neither their form nor size. The micro-spectroscope shows a strong absorption of all the rays whose wave-length is less than $62 \mu$, especially of those between .62 and 59 (orange). It is sensitive in a high degree to the influence of light. (For details, see Jour. Roy. Micr. Soc., r882, p. 656 , and 1883 , p. 256 .)

103. B. chlorinum, Engelmann (l.c., p. 276).

Cells $2-3 \mu$ long, motile, of a greenish colour, paler than that of a chlorophyll granule of the same size. It presents in a high degree the tendency to accumulate in the light, but only when oxygen is absent; according to the author, it disengages oxygen in the light, and is therefore not a Schizomycete at all.

104. B. viride, Van Teighem (Bull. Soc. Bot. France, r880, p. r74).

Rods minute, of a pure green colour, constricted in the middle, dividing frequently, and separating after each segmentation, but otherwise immotile. In a large number of 


\section{Bacillus.}

rods it forms spores, colourless, very refringent, of a spherical or slightly oval form, like those of a Bacillus.

In the rain-water which filled the cavity of the pileus of a young Polyporus, forming a thin layer.

This can scarcely be a Bacterium. The colouring matter, according to Van Tieghem, is true chlorophyll. He compares it to B. lucens.

Wakker records (Bot. Centralblatt, 1883, p. 315) a Bacterium resembling $B$. Termo, causing the "yellow disease" of hyacinths. It occurred in a yellow slime in the bulbs in autumn, and in the leaves in spring. He calls it $B$. hyacinthi.

\section{BACILLUS.}

ro5. B. crassus, Van Tieghem (Bull. Soc. Bot. France, 1879, p. 142).

Cells motionless, large, resembling $B$. Ulna, $4 \mu$ broad during active growth, $5^{-6} \mu$ when forming spores. Spores spherical, $5 \mu$ in diameter.

The spores of this species are the largest known among the Schizomycetes. It does not produce starch.

106. B. malariæ, Tommasi-Crudeli (Atti R. Accad. Lincei, Trans., vi., r881, p. 19).

In the spleen, the medulla of bones, the lymphatic glands, and the venous blood of persons suffering from malarial fever. The evidence of the existence of this species is at present unsatisfactory.

107. B. puerperalis, Engel (Comptes Rendus, lxxxviii., r879, p. 976).

In the blood of a woman who had died in childbirth. Engel observed the production of conidia.

108. B. mollusci, Domenico (Atti R. Accad. Lincei, Trans., v., 1880).

Resembling $B$. lepra. In the nodules of Molluscum contagiosum. 
90 Synopsis of the Bacteria and Yeast Fungi.

I09. B. virens, Van Tieghem (Bull. Soc. Bot. France, I880, p. 175).

? Leptothrix tenuissima, Rabenhorst.

? L. subtilissima, Rabenhorst.

? Sporonema gracile, Perty. (Fig. 78.)

Filaments slender, of a greenish-yellow colour, usually

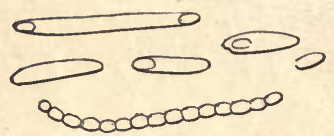
immotile, but sometimes moving; cells long, resembling those of $B$. anthracis, forming a very Fig. 78.-Sporonema gracile (after Perty). refringent, oval, colourless spore, slightly thicker than the threads. Spores in germinating put forth a slender filament, soon septate, at first colourless, but becoming green like the original threads in the light.

In stagnant water among Spirogyra.

Perty observed the spores of this species, if it is identical with his Sporonema. It seems a doubtful Schizomycete.

\section{I0. B. beribericus, De Lacerda.}

This has been discovered in the blood of patients suffering from the disease known in the tropics as beri-beri. It consists of cylindrical, articulated, branched (?) filaments, containing sometimes brilliant refringent points, which are believed to be spores. The filaments cultivated after Pasteur's method, with due precautions, and injected into rabbits, caused all the symptoms of beri-beri. M. de Lacerda believes that the parasite is originally derived from rice which has undergone a peculiar alteration (Lancet, February 9, 1884, p. 268).

\section{Bacillus of Cholera.}

The Commission sent out by the German Government, under Dr. Koch, has observed in the bodies of cholera 
patients in India, in every case, the same Bacilli that they found in Egypt. But it was still undecided whether these Bacilli did not belong to the regular parasites of the gut, having made their way into the mucous membrane of the intestine under the influence of the cholera disease. Some of the Bacilli were, therefore, isolated from the intestinal contents of the purest cholera cases and cultivated in gelatine, so as to investigate their distinctions from other Bacilli. In this way it was demonstrated that this kind of Bacillus was present in all the choleraic evacuations examined, as well as in all the intestinal contents from persons who had died of cholera. On the other hand, the bodies of eight persons who had died of pneumonia, dysentery, phthisis, and kidney-disease were examined, as well as the bodies of several animals, and other substances abounding in bacteria, but in none of these cases was the cholera Bacillus found. It is also reported that the same organism was discovered in water from a tank, which had been suspected of being a source of the disease.

\section{Bacillus of Syphilis.}

Despite the strenuous efforts which have been made to demonstrate the existence of a specific Bacillus of syphilis, it must be admitted that the evidence is as yet inconclusive.

There are also described the Bacillus of the pneumo-enteritis of the pig (Klein, Proc. Roy. Soc., xxvii. p. Ior), which resembles B. anthracis, but differs in the cylindrical spores, which measure only $5 \mu$ in length; the Bacillus of malignant œdema (Koch); $B$. urea (Miquel); and a Bacillus in a badger's liver (Eberth). 


\section{DISPORA.}

III. D, Caucasia, Kern (Bot. Zeitung, xl, I882, p. 264).

Cells resembling $B$. subtilis, $3^{\cdot 2-8} \mu$ long, $\cdot 8 \mu$ broad, with a flagellum at each end. Forming long leptothrix threads by growth and cell-division, and then producing spores, which "stand on their ends," two in each cell. Spores round, $8 \mu$ in diameter, afterwards increasing tu I $\mu$.

In "kephir," a drink prepared by the inhabitants of the high-lying lands of the Caucasus, by fermentation of cows' milk. (See Nature, 1882, p. 43, and Jour. Roy. Micr. Soc., I882, p. 383.)

This may be the result of mal-observation. In $B$. subtilis, when a cell is elongated, and about to divide, two spores are sometimes found in one cell.

\section{BEGGIATOA.}

I I 2. B. nodosa, Van Tieghem (Bull. Soc. Bot. France, I880, p. I76).

Filaments colourless, very slender, motionless ; articulations shorter than broad; no sulphur granules. At intervals some of the cells become more refringent, enlarge, and persist like spores, and form nodosities on the filament. Similar monstrosities exist, according to Van Tieghem, in true Oscillarias. This is not a true Beggiatoa.

\section{PHRAGMIDIOTHRIX, Fingler.}

Differs from Beggiatoa in the want of sulphur granules and the continuous subdivision of the cells, and from Crenothrix in the want of a sheath. 
I 13. P. multiseptata, Engler ("Pilz-veg. weiss. oder todt. Grundes in der Kieler Bucht").

Beggiatoa multiseptata, Engler (Sitz.-Bericht. Bot. Ver. Provinz Brandenburg, 1882, p. 17).

Threads $3-6 \mu$ broad, separated by transverse partitions into short cylinders, whose height is only one-fourth to onesixth of their breadth. These discs are separated by repeated transverse and longitudinal division into cocci, which probably become isolated. From these cocci very slender threads arise which afterwards become thicker.

Attached to the legs of crabs (Gammarus) in sea-water.

\section{LEPTOTHRIX.}

I14. L. gigantea, Miller (Ber. Deutsch. Bot. Gesell., I 883 , pp. 22 I-224, pl. vi.).

Occurred as bundles or tufts of diverging threads, which varied very considerably in thickness in the same tuft, from '5-4 $\mu$; threads $250 \mu$ long or more, showing a distinction between base and apex, the thicker ones consisting of articulations, which formed cocci, short rods, or long rods, sometimes all in the same thread. Some of the threads showed a sheath, from which the articulations passed out, collecting in a heap at the extremity. Articulations

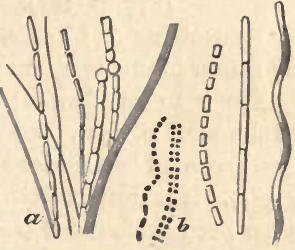

Fig. 79.-Leptothrix gigantea. $a$, base of a tuft of threads, $\times 540 ; b$, stages of subdivision of the threads (after Miller). round, oblong, or pear-shaped; the larger ones dividing into smaller, first by a transverse and then by a longitudinal septum. Some of the threads assumed a spiral form, and even approached Spirochæte.

(Fig. 79.) 


\section{Synopsis of the Bacteria and Yeast Fungi.}

In the teeth of a dog suffering from Pyorrhoea alveolaris, and subsequently in the bite of other carnivorous and herbivorous mammals, sheep, cattle, pigs, horses, cats, etc. The subdivision of the larger cocci and the septation of the finer threads were only made visible by staining.

This is considered by Miller as affording a very strong proof of the truth of Zopf's theory. It resembles Beggiatoa alba and Crenothrix Kiühniana. Miller also found the same stages in $L$. buccalis (see Fig. 27a) in carious teeth; in this the cocci penetrated into the tooth more deeply than the rods, and they in turn than the longer threads (supra, p. 72). It is to be remarked, however, that what are here called cocci, rods, and spiral forms are not the exact counterparts of typical Micrococci, Bacteria, and Spirilla. (See also F. Y. Clark, in Johnston's Dental Miscellany, 1879, p. 447, who describes a Bacterium in the teeth, $x^{\cdot} 5-3 \mu$ long, $\cdot 5 \mu$ broad, of a somewhat spiral form.)

\section{SPIRILLUM.}

I1 5. S. rosaceum, Klein (Quart. Jour. Micr. Sci., xv., 1875 , p. 38r).

Resembling $S$. Undula, but reddish in colour; colouring matter insoluble in water, alcohol, or chloroform.

Seems to be identical with S. rufum, Perty (Pritchard, "Infusoria," p. 534), and possibly not different from the form recorded by Geddes and Ewart (Proc. Roy. Soc., 1878, p. 482 ). It is distinct from $S$. sanguineum, Cohn, with which it has been confounded (see also Bacterium rubescens, p. 85).

Ir6. Spirulina alba, Van Tieghem (Bull. Soc. Bot. France, 1880, p. 177).

Absolutely colourless. Filaments very long and slender, resembling $S$. tenuissima. Coils so close together as almost to touch and form a hollow tube. Turning actively round its axis, and also oscillating laterally as a whole.

Forming a thin white layer on the muddy bottom of 
an abandoned mill-race. This, if the want of colour were not accidental, would appear to be a Schizomycete.

\section{CRYPTOCOCCUS.}

\section{7 . C. xanthogenicus, Freire.}

Resembling a Micrococcus. Said to have been discovered in Brazil, in persons suffering from yellow fever.

Dr. Freire, having .cultivated this in gelatine for six generations, says that, when introduced into the body by "vaccination," it produced a mild type of yellow fever; he had previously observed that rabbits and guinea-pigs, so inoculated, were proof against the fatal type of the disease.

Micrococcus sp. W. Archer describes (Quart. Jour. Micr. Sci., xiv., 1874, p. 321) a "black" Micrococcus, really blue-black, consisting of cells rounder than in $M$. prodigiosus, arranged in twos or fours, the latter in a square, not in a straight line.

\section{SARCINA.}

I 8 . S. solani, Reinke et Berthold ("Die Zersetzung der Kartoffel durch Pilze," p. 22, pl. vii. fig. 13).

Cells small, colourless, round or before division oval; some free, others collected in unilamellar colonies of from 4 to $24 ; I^{3} 3^{-2} \mu$ in diameter. (Fig. 80.)

In rotting potatoes. (See Bacterium merismopedioides, Zopf, supra, p. 84, with which this seems to be identical.)

I have found a very similar Schizomycete in putrefying starch-paste, which differed in scarcely any respect except its much larger size, the colourless cells being perfectly round and 6-8 $\mu$

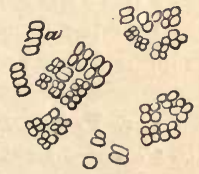

Fig. 80.-Sarcina solani. $a$, side view of two plates, $\times 940$ (after Reinke and Berthold). in diameter. It occurred singly or in pairs or fours, always unilamellar, the tetrads being collected together in families of 16,24 , or more cells. 
96 Synopsis of the Bacteria and Yeast Fungi.

POLYBACTERIA, Van Tieghem (Bull. Soc. Bot. France, 1880, p. 149).

Under this and the following genera, Van Tieghem places some bacteria which are probably only zooglœa stages of other species, like Ascococcus, which they resemble.

rig. P. catenata, Van Tieghem (l.c., p. 150).

Colonies naked, oval, colourless, composed of short rods aggregated without order; the colonies divide transversely in such a manner as to remain attached end to end in a flexuous chain.

In a decoction of horse-dung.

1 20. P. sulfurea, Van Tieghem (l.c., p. r5o).

Colonies rounded or polyhedral, composed of short rods of a sulphur colour; the colonies divide in two directions at right angles to one another, so as to form a simple layer.

On the surface of a liquid in which haricot-beans were decaying.

PUNCTULA, Van Tieghem (l.c., p. r5o).

Differing from Polybacteria, in the cells of which it is composed being round.

I 2 I. P. rosea, Van Tieghem (l.c., p. 150).

Colonies single, of a bright rose colour, spherical; cells round, extremely small, arranged in radiating lines and concentric circles.

12 2. P. cubica, Van Tieghem (l.c., p. 150).

Colonies cubical, dividing successively parallel to each 
face, so as to form cubical masses. Cells rather larger than in $P$. rosea, colourless, round.

123. P. glomerata, Van Tieghem (l.c., p. I50).

Colonies rounded, colourless, dividing in three directions, and remaining associated in lobed masses.

All three forms were met with on putrefying seeds.

ASCOBACTERIA, Van Tieghem (l.c., p. I5 I).

This consists of colonies surrounded by a thick gelatinous membrane, and bears the same relation to Polybacteria that Cohn's Ascococcus does to Punctula.

124. A. ulvina, Van Tieghem (l.c., p. 151).

Colonies polyhedral, enveloped in a thick cartilaginous membrane, forming a coherent membrane like an Ulva, composed of short rods aggregated without order, which increase by bipartition.

On the surface of liquids in which leguminous seeds, especially of lupin, were decaying.

\section{ASCOCOCCUS, Cohn.}

125. A. vibrans, Van Tieghem (l.c., p. $5_{5}$ I).

Similar to $A$. Billrothii, but the cells oscillated and whirled round, as in the Brownian movement.

On the surface of water in which Beggiatoa was growing.

All these aggregated bacteria of Van Tieghem live on the surface of fluids, and often, if not always, disengage ammonia, like Ascococcus. 
98 Synopsis of the Bacteria and Yeast Fungi.

\section{MONAS.}

The following species, placed under Monas, are considered by Warming to belong to the Schizomycetes :-

x26. M. vinosa, Ehrenberg ("Die Infusionsthierchen," p. II).

Chromatium violascens, Perty.

Cells ovate, rounded at each end, very small, $2-4 \mu$, of a wine-red colour. Motion very slow and (8) 8 (8) 1 tremulous.

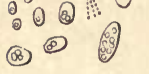

Fig. 8r.-Monas vinosa (?) $\times 66$ o(after Warming).
The form which Warming considers identical with this is spherical or more commonly oval, $\cdot 5-4 \mu$ in length, pinkishred, granular, actively motile, with a flagellum. (Fig. 8r.)

In water containing decaying vegetable matter.

127. M. Okenii, Ehrenberg (l.c., p. 15).

Chromatium Weissii, Perty.

Cells cylindrical, equal, slightly curved, abruptly rounded at each end; 7-r $5 \mu$ long, but, according to Warming,

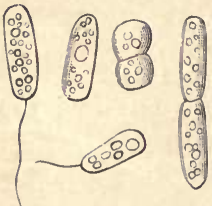

Fig. 82.-Monas Okenii, $\times 660$ (after Warming). much longer, $5 \mu$ broad, of a bright red colour, motile; the granules are pretty evenly distributed throughout the body; furnished with a flagellum, in the large specimens one at each end. Movements slow. (Fig. 82.)

In stagnant water. According to L. Olivier (Bull. Soc. Bot. France, 1882 , p. 216), M. Okenii, which Lankester admitted to be one of the forms described by him under Bacterium rubescens, is not a Schizomycete, but a true monad, 
destitute of ternary envelope, and he places it among the Nudo-flagellata.

I28. M. Warmingii, Cohn.

Cells cylindrical, rounded at the ends, pinkish, with the granules accumulated at the extremities; $15 \mu$ long, 5-6 $\mu$ broad (according to Warming), $8 \mu$ (Cohn), with a flagellum. Movements rapid, but irregular. (Fig. 83.)

In brackish water.

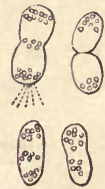

Fig. 83. - Monas Warmingii, $\times 660$ (after Warming).

I 29. M. erubescens, Ehrenberg (l.c., p. II).

Warming considers this identical with $M$. Warmingii, differing only in having the granules equally distributed; I4 $\mu$ long, 6-7 $\mu$ broad.

In brackish water.

I30. IM. gracilis, Warming (l.c., p. 6 of the Resumé).

Cells straight, cylindrical, slender, rounded at the ends, pinkish; $60 \mu$ long or less, $2 \mu$ broad; paler than $M$. Okenii, with few sulphur granules. Movements slow ; sometimes slightly curved. (Fig. 84.)

In fresh water.

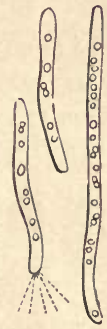

Fig. 84,-Monas gracilis, $\times 660$ (after Warming).

I3I. M. Mülleri, Warming (l.c., p. I 8 of the Resumé). Volvox punctum, Müller.

Cells spherical or oval, $5^{\cdot 6-15} \mu$ long, having usually one extremity filled with angular and very refringent granules, the other empty and hyaline. Granules whitish, 
100 Synopsis of the Bacteria and Yeast Fungi.

with a blue tinge and a dark border. Movements incessant. A flagellum (?). (Fig. 85.)

In sea-water.

I32. M. fallax, Warming (l.c., p. I8 of the Resumé).

Cells small, $4-5 \mu$ long, $3 \mu$ broad, oval, sometimes

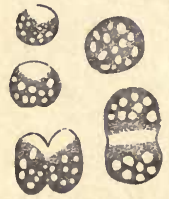

Fig. 85.-Monas Malleri, $\times 660$ (after Warming).

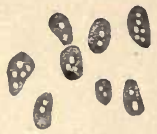

Fig. 86.-Monas fallax, $\times 660$ (after Warming).

curved or angular, and almost entirely filled with crystalline and very refringent granules. Movements rapid. (Fig. 86.)

Warming considered that some of these monads may be the zoospores of Beggiatoa.

133. Rhabdomonas rosea, Cohn.

Cells fusiform, pinkish, granular; $20-3 \circ \mu$ long, 4-5 $\mu$ broad. Movement slow; with
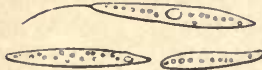

$0000.0000 \times 000000$

Fig. 87, - Rhabdomonas rosea, $\times 600$ (after Cohn). a flagellum. (Fig. 87.)

Some of Warming's specimens were cylindrical, 3-4 $\mu$ broad, 15-35 $\mu$ long, or more; but he figures spindle-shaped forms as well.

In brackish and fresh water. 


\section{APPENDIX A.}

\section{On the Unit of Microscopical Measurement.}

IT has for some time been the general practice on the Continent, and is beginning to be so in England, to give the dimensions of microscopic objects in terms of a thousandth of a millimetre, which is called a micro-millimetre, and is variously designated by the abbreviations $\mu, m k$., and $m m m$. The first abbreviation, being the shortest, is the most generally adopted ; but there seems still to be a prejudice existing against this unit, from a want of knowledge of the advantages which its use confers or of the mode of using it. In the first place, it is always easier to conceive the size of any object, and especially to realise the comparative sizes of two objects, when their dimensions are given in terms of a unit smaller than either; for instance, it is difficult exactly to comprehend the length represented by $\frac{1}{289}$ of an inch, and few people can readily compare such dimensions as $\frac{1}{15}$ and $\frac{1}{2} \delta$ of an inch.

All this difficulty vanishes when the dimensions are expressed as multiples of a small, properly chosen unit, and not as fractions of a large one. For this purpose a fraction of an inch might be adopted instead of a fraction of a millimetre; but, at any rate in measuring the spores of Fungi, 10000 of an inch is too large a unit, and $\frac{1}{100000}$ of an inch would be inconveniently small. It happens that, if we take $\frac{1}{1000}$ of a millimetre as our unit, we can express the size of the spores of all Fungi, and also of many other microscopic organisms, in the fewest possible figures. For instance, many of the Micro- 
cocci measure about $I \mu$, the spores of Penicillium about $3 \mu$, the spores of many Myxomycetes about 1o $\mu$, and so on. If we compare these figures with the following : $\circ 1 \mathrm{~mm}$., ${ }^{\circ} \infty 3 \mathrm{~mm}$., or mm., or still more with these : 00004 in., 00012 in., .0004 in.,-we see the great saving effected in the trouble of writing down the dimensions, quite apart from the greater readiness with which they can be compared with one another.

But perhaps the difficulty with some is that of realising and actually applying this unit; I will therefore give an easy method by which the size of the micro-millimetre may be obtained. Place your microscope in such a position that the image projected upon a piece of white paper is magnified 254 times : this can easily be done by a quarter-inch objective with the use of the draw-tube, or by placing the paper at a greater distance than ten inches from the eye-piece. Let this position be marked, so that the microscope can be placed in it again at any timeNow copy on the paper, from a scale, an inch divided into ten parts, and with a fine pen subdivide each tenth into five equal parts. Then the value of each of these subdivisions will be $2 \mu$, and of the whole tenth of an inch, 10 $\mu$. If this scale be carefully copied on a piece of thin cardboard or other suitable substance, the dimensions of any minute object, drawn by the camera or otherwise on the paper in that position of the instrument, can be easily read off in $\mu$ 's. With the aid of a deeper eye-piece or higher objective we can magnify the image 508 times, and then each small division of the scale will represent I $\mu$. 


\section{APPENDIX B.}

\section{ON the Staining of "Bacillus Tuberculosis."}

Professor Koch (Verh. Physiol. Gesell., Berlin, I882, p. 65) first announced the discovery of the Bacillus of tuberculosis. He placed the fluid from the diseased tissues in a mixture of I c. cm. of a concentrated solution of methylene blue in alcohol, $0.2 \mathrm{c}$. cm. of a ro-per-cent. solution of potash, and $200 \mathrm{c} . \mathrm{cm}$. of distilled water. By this the preparation is coloured blue, and a few drops of a solution of vesuvin are then placed on it. This discharges the blue from every part except the Bacilli, which remain blue in a brown field, but are not easily seen.

Ehrlich's method, especially as modified by Heneage Gibbes, is more successful. The colours used by the latter are magenta crystals and chrysoidin, which is a brown that does not stain the ground so intensely as vesuvin. ( $\mathrm{I}$ ) Take $2 \mathrm{grm}$. of magenta crystals, $3 \mathrm{grm}$. of pure aniline, $20 \mathrm{c.} \mathrm{cm}$. of alcohol (specific gravity, 830), $20 \mathrm{c}$. cm. of distilled water. Dissolve the aniline in the spirit, and rub up the crystals with it in a glass mortar, adding the spirit gradually till they are all dissolved; then add the water slowly, while stirring, and keep in a stoppered bottle. (2) Make a saturated solution of chrysoidin in distilled water, and add a crystal of thymol to make it keep. (3) Make a dilute solution of commercial nitric acid, one part of acid to two of distilled water. Spread a thin layer of sputum on a cover-glass, and let it dry ; when quite dry pass it two or three times through the flame of a small Bunsen burner, and let it cool. Filter two or three drops of the magenta 
solution in a watch-glass; place the cover-glass, with the sputum downwards, on the stain, taking care that there are no air-bubbles under it. Let it remain for fifteen or twenty minutes; then wash in the dilute acid till all colour has disappeared. Remove the acid with distilled water ; then place the cover-glass in the same manner as before on a few drops of chrysoidin, filtered into the bottom of a watch-glass, and let it remain for a few minutes till it has taken a brown stain. Wash off the superfluous colour in distilled water, and place the coverglass in absolute alcohol for a few minutes. Then remove and dry perfectly in the air, and mount in a solution of Canada balsam. The Bacilli are visible with a quarter-inch objective. (See Lancet, ii., 1882, p. 183.) By this process only B. tuberculosis is stained, the ordinary putrefactive bacteria remaining colourless.

Prideaux (l.c., p. I138) uses methylene-blue instead of chrysoidin for staining the ground; by this means the Bacilli show up red on a blue background. The process may fail if the solutions are at a lower temperature than $100^{\circ} \mathrm{F}$., and Professor Brun recommends that the sputum should not be exposed to a greater heat than $176^{\circ} \mathrm{F}$. If gentian violet be used, after the nitric acid treatment, the putrefactive bacteria will be stained, and not the tubercle bacilli, which are thus strongly differentiated. The latter are also stained by fuchsin.

The following is Heneage Gibbes's rapid method of demonstrating $B$. tuberculosis without nitric acid. Take of rosaniline hydrochloride 2 grm., methyl-blue $\mathbf{I}$ grm.; rub in a glass mortar. Then dissolve aniline oil $3 \mathrm{c}$. $\mathrm{cm}$. in rectified spirit I 5 c. cm. ; add the spirit slowly to the stain till all is dissolved; then slowly add distilled water $15 \mathrm{c}$. $\mathrm{cm}$.; and keep in a stoppered bottle. Place a few drops of the stain in a test-tube, and warm; as soon as steam rises, pour into a watch-glass, and place the cover-glass as before. After four or five minutes wash in methylated spirit till no more colour comes away; drain thoroughly, and dry either in the air or over a spirit-lamp. Mount in Canada balsam. A section of tissue containing Bacilli can be treated in the same way, only it must be left in the stain for several hours. 


\section{$105)$}

\section{APPENDIX C.}

DISEASES PRODUCED BY THE SCHIZOMYCETES.

THE following classification of the Schizomycetes and the diseases produced by them, arranged according to Cohn's system, was read before the British Medical Association, by Dr. Julius Dreschfeld, in $188_{3}$ :-

I. SpHerobacteria (Micrococci) : spherical or oval cells, rather less than $I \mu$ in diameter, occurring singly or in pairs (diplococci) or . in masses (zooglœa).

a. Chromogenous-M. prodigiosus.

b. Zymogenous $-M$. urea.

c. Pathogenous-In the following diseases :-

Acute abscess.

Pyæmia.

Septicæmia.

** Septicæmia in mice (Koch).

** Erysipelas.

Osteomyelitis.

Endocarditis ulcerosa.

* Diphtheria.

** Gonorrhœa.

* Pneumonia.

Cerebro-spinal meningitis (Aufrecht).

Cerebral meningitis (Leyden).

Acute yellow atrophy of liver.

Variola.

Scarlatina.

Measles.

Typhus (Mott).

** Those diseases in which it is fully established that the microorganism is the causal agent ; * those in which it is less fully proved; the rest are doubtful. 
Syphilis (Birsch-Hirschfeld, Klebs).

Dysentery (Prior).

Whooping-cough (Burger).

II. MICROBACTERIA : small cylindrical or elliptic rods, occurring singly or in pairs or in zooglnea masses.

a. Chromogenous-Bacterium synxantham (in yellow milk). $B$. aruginosum (in blue pus).

b. Zymogenous-B. Termo (in putrefaction).

$B$. Lineola (in stagnant water).

Mycoderma aceti (in acetic acid fermentation).

c. Pathogenous-In ** Septicæmia of rabbits (Koch).

** Chicken cholera (Pasteur).

Typhus? (Klebs).

III. DESMOBACTERIA.

I. BACILLI : longer rods, often showing the formation of spores.

a. Chromogenous-Bacillus ruber (in boiled rice).

b. Zymogenous- $B$. subtilis (in hay infusion).

$B$. butyricus (in butyric acid fermentation).

c. Pathogenous-In the following diseases:-

** Anthrax.

** Glanders.

** Septicæmia in mice (Koch).

Malignant œedema of animals and of man (Ehrlich).

Meat-poisoning in man (Klein).

Typhoid fever.

Malaria.

Diphtheria (Klebs).

Lepra.

** Tuberculosis (including tuberculosis, phthisis, scrofula, lupus, and heart-disease of animals).

2. LEPTOTHRIX : longer rods and fibres, often occurring in bundles, and found in the saliva, etc., L. buccalis.

IV. SPIROBACTERIA : threads forming spirals.

I. SPIRILlum : spirals rigid; $S$. serpens (in stagnant fluids).

2. Spirocheta: spirals not rigid.

In the tartar, and in caries of the teeth.

** $S$. Obermeieri (in relapsing fever).

Actinomyces, which is introduced into this list by Dr. Dreschfeld, is a Hyphomycete, and does not belong to this class of Fungi. 


\section{INDEX.}

The references are to the pages. The names of genera and species quoted as synonyms or mentioned in passing are printed in italics.

A

Acetification, 65, 85, 106

Actinomyces, 106

Alcohol, 57

Alopecia, 87

Ammonia, 9, 15, 97

Anthrax, 30, 106

Aphtha, 66

Ascobacteria, 97

- ulvina, Van T., 97

Ascococcus, 15, 96

- Billrothii, Cohn, 15

mesenterioides, Cien., I6

vibrans, Van T., 97

\section{B}

Bacillus, 26, 89

Amylobacter, $\operatorname{Van} T$., 29, 50 anthracis, Cohn, 30 beribericus, De Lac., 90 crassus, Van T., 89 erythrosporus, Cohn, 33 formation of spores, 3 germination of spores, 4,28 lepræ, Hansen, 32 malariæ, Tomm., 89 mollusci, Dom , 89
Bacillus of cholera, 90 of syphilis, 9 I

— puerperalis, Eng., 89 ruber, F. et $C$., 33 subtilis, Cohn, 3, 27

- suis, Detmers, 13

- tremulus, Koch, 28

- tuberculosis, Koch, 5, 45, I03

- Ulna, Cohn, 30

-urea, Miquel, 9I

- virens, $\operatorname{Van} T$., 90

Bacteria, aggregated, 96

Bacteriaceæ, 75

Bacteridium aurantiacum, Schr., 8

- cyaneum, Schr., 9

- luteum, Schr., 8 prodigiosum, Schr., 7 violaceum, Schr., 9

Bacterio-purpurin, 18, 85

Bacterium, 22, 75

- aceti, Zopf, 85

- æruginosum, Schr., 26

- chlorinum, Eng., 88

- decalvans, Thin, 87

- fotidum, Thin, 87

- fusiforme, Warm., 25

- griseum, Warm., I4

- hyacinthi, Wakk., 89

- lactis, Lister, 86

- Lineola, Cohn, 24 
Bactcrium litoreum, Warm., 24

— lucens, $\operatorname{Van} T$., 88

- merismopedioides, Zopf, 84,

95

Navicula, $R$. et $B ., 25$

photometricum, Eng., 88

rubescens, Lank., 17, 85

sulfuratum, Warm., 86

- syncyanum, Schr., 26

- synxanthum, Schr., 25

- Termo, Duj., 10, 23

- triloculare, Ehr., 24

- violaceum, Gr., 26

— viride, $\operatorname{Van} T$., 88

- Zopfii, Kurth, 83

Beer, fermentation of, $59,61,62$ Beet-root sugar, 16

Beggiatoa, 36, 75

- alba, Trev., 36, 73

- - marina, Cohn, 37

- arachnoidea, Rab., $3^{8}$

— leptomitiformis, Trev., 38

— minima, Warm., 40

— mirabilis, Cohn, 39

- multiseptata, Eng., 93

- nivea, Rab., 37

nodosa, $\operatorname{Van} T$., 92

- Erstedtii, Rab., 37

- pellucida, Cohn, 38

- punctata, Trev., 36

85

roseo-persicina, Zopf, I8, 74,

tigrina, Rab., 39

Beri-beri, 90

Blood-rain, 7

Blue milk, 26

Butyric fermentation, 28, 29

\section{C}

Caries of the teeth, 35, 44, 94, 106 Carpozyma apiculatum, Eng., 62

Cellulose fermentation, 29

Chicken-cholera, 13, 106

Chinch-bug, 13

Chlorophyll, 88, 90

Cholera, I3, 90

Chromatium violascens, Perty, 98

—W Wissii, Perty, 20, 98
Chromobacteriumviolaceum, Berg., 26

Chromogenous species, 5

Chroococcus, 75

Cladothrix, 40, 75

- dichotoma, Cohn, 4I, 73

Försteri, Wint., 4I

Clathrocystis, 17

- aruginosa, Henf., 17

- roseo-persicina, Cohn, 18

Clostridium, 75

- butyricum, Prazm., 29

Coccaceæ, 75

Cohnia, I7

- roseo-persicina, Wint., 17,

74

Consumption, 32

Crenothrix, 54, 75

- Kühniana, Zopf, 55

- polyspora, Cohn, 55

Cryptococcus

cerevisia, Kütz., 58

- fermentum, Kütz., $5^{8}$

- glutinis, Fres., 63

- guttulatus, Rob., 66

xanthogenicus, Freire, 95

Cultivation, Pasteur's, 78

\section{D}

Desmobacteria, 69, 106

Diphtheria, I I, I05, 106

Diseases produced by Schizomycetes, 105

Dispora, 92

Caucasia, Kern, 92

Drilosiphon Fulianus, Zuk, 72

Dysentery, 106

E

Erysipelas, 105

\section{F}

Fermentation, I, 57, 64

- alcoholic, 57 
Fermentation, butyric, 28, 29

- lactic, 87

- of beer, 59, 61, 62

- of cellulose, 29

- of milk, 92

- of starch, Io

- of tomatoes, 62

of urine, 9

of wine, $60,61,62$

Fire-blight, 10

\section{G}

Gattine, 14

Glanders, 106

Glaucothrix, 75

Gliothrix, 75

Gonorrhœa, 105

H

Homatococcus, 76

Hog-cholera, I3

Hormiscium

- album, Bonord., 63

- cerevisia, Bail, 59

- cerevisia, Bonord., 64

- vini, Bonord., 64

Hygrocrocis Vandelli, Men., 36

Hypheothrix Kïhniana, Rab., 55

K

Kephir, 92

L

Lactic fermentation, 87

Leprosy, 32, 106

Leptonema niveum, Rab., 37

Leptothrix, 34, 75

- buccalis, Rob., 34, 94

- gigantea, Mill., 93

- Kühniana, Rab., 55

- Lanugo, Kiitz., 35

ochracea, Kütz., 73
Leptothrix parasitica, Kütz., 35, 73

- pusilla, Rab., 35

- subtilissima, Rab., 90

- tenuissima, Rab., 90

Leuconostoc, 16, 75

- mesenterioides, Van $T$., 16

\section{M}

Malaria, 89, 106

Measles, 13, 105

Melanella flexuosa, Bory, 47

- Spirillum, Bory, 50

Merismopedia

— Goodsirii, Hus., 20

- hyalina, Kütz., 22

- litoralis, Rab., $2 \mathbf{I}$

- urina, Rab., 21

- ventriculi, Rob., 20

- violacea, Kütz., 22

Merismopedium

- chondroideum, Wittr., 22

Reitenbachii, Casp., 21

Microbacteria, 69, 106

Micrococcus, 6, 13,95

- amylivorus, Burr., 10

- aurantiacus, Cohn, 8

- black, 95

- bombycis, Cohn, 12

- candidus, Cohn, Io

- chlorinus, Cohn, 8

- Crepusculum, Cohn, 10

- cyaneus, Cohn, 9

- diphtheriticus, Cohn, II

— fulvus, Cohn, 8

- gallicidus, Burr., I3

- griseus, Wint., 14

- insectorum, Burr., I3

- luteus, Cohn, 8

- ovatus, Wint., 14

- prodigiosus, Cohn, 7

- septicus, Cohn, 12

- suis, Burr., 13

- toxicatus, Burr., 15

- ureæ, Cohn, 9

- vaccinæ, Cohn, II

violaceus, Cohn, 9

Microhaloa rosea, Küitz., 17

Micro-millimetre, IOI 
Microsphara vaccina, Cohn, II Microsporon septicum, Klebs, 12 Microzyma bombycis, Béch., 12 Molluscum, 89

Monads, 2, 98

Monas, 98

Crepusculum, Ehr., 10

- erubescens, Ehr., 86, 99

__ fallax, Warm., 100

_- gracilis, Warm., 86, 99

- Mülleri, Warm., 99

- Okenii, Ehr., 20, 85, 98

- prodigiosa, Ehr., 7

- Termo, Müll., 23

- vinosa, Ehr., 86, 98

- Warmingii, Cohn, 86, 99

Monostroma rosea, Curr., I8

Mucor-ferment, 67

Mucorini, 76

Mucor Mucedo, Linn., 8o

- racemosus, Fres., 67

Mycoderma

_erevisia, Desm., 64

- vini, Desm., 64

Myconostoc, 4I

gregarium, Cohn, 42

Mycoprotein, 74

\section{$\mathbf{N}$}

Nosema bombycis, Näg., I4

Nudo-flagellata, 99

\section{$\mathrm{O}$}

CEdema, malignant, 91, 106

Oidium albicans, Rob., 65

Ophidomonas, 46

— Fenensis, Ehr., 53

- sanguinea, Ehr., 51, 53

Oscillaria

__ alba, Vauch., 36

—_arachnoidea, Ag., 38

- leptomitiformis, Men., 38

- tigrina, Röm., 39

— versatilis, Kütz., 38
$\mathbf{P}$

Palmella infusionum, Ehr., 23

- mirifica, Rab., 8

- prodigiosa, Mont., 7

Palmellina flocculosa, Radl., 55

Panhistophyton ovatum, Leb., I4

Pathogenous species, 5

Pébrine, 14

Penicillium, 77, 80

Phragmidiothrix, 75, 92

- multiseptata, Eng., 93

Phthisis, 32, 106

Phycochromaceæ, 1, 34

Pleomorphy, 76, 80

Pleurococcus roseo-persicinus,

Rab., 17

Pneumo-enteritis of pig, 91

Pneumonia, 105

Polybacteria

- catenata, $\operatorname{Van} T ., 96$ sulfurea, $\operatorname{Van} T$., 96

Protean species, 78,83

Protococcus roseo-persicinus, Kiitz., 17

Punctula

- cubica, Van $T$., 96 glomerata, Van T., 97

- rosea, Van T., 96

Pus, blue, 26

Pustula maligna, 31

Putrefaction, 10, 23

Pyæmia, 12, 105

Pyorrhoea, 94

\section{R}

Recurrent fever, 44, 106

Rhabdomonas

- rosea, Cohn, 86, 100

\section{S}

Saccharomyces, $5^{8}$

- albicans, Reess, 65

- apiculatus, Reess, 62

- cerevisiæ, Mey., 58, 67 
Saccharomyces conglomeratus, Reess, 60

- coprogenus, S. et $S ., 66$

- ellipsoideus, Reess, 60

exiguus, Reess, 6I

formation of spores, 57

glutinis, Cohn, 63

guttulatus, Wint., 66

minor, Eng., 59

Mycoderma, Reess, 64

olei, Van T., 67

Pastorianus, Reess, 6r sphæricus, Sacc., 62

Saccharomycetes, 57, 79

Sarcina, 20, 95

— hyalina, Wint., 22

- litoralis, Wint., 21

- Reitenbachii, Wint., 21

- renis, Hepworth, 22

- solani, R. et B., 95

- urinæ, Welck., 21

—_ ventriculi, Good., 20

Scarlet fever, 13, 105

Schizomycetes, I, 68

Schizophyceæ, 76

Schizophytæ, 1, 70

Schlaffsucht, I 2

Scrofula, 106

Septicæmia, I2, 105, 106

Silkworm disease, 12, 14

Small-pox, II, IO5

Sphærobacteria, 69, I05

Sphærotilus, 53

- natans, Kütz., 53, 56

- ochraceus, Bréb., 54

Spirillum, 46, 94

- amyliferum, $\operatorname{Van} T$., 50

- attenuatum, Warm., 52

- Jenense, Wint., 53

— plicatile, Duj., 43

rosaceum, Klein, 94

Rosenbergii, Warm., 52

rufum, Perty, 94

- Rugula, Wint., 47

- sanguineum, Cohn, 51, 94

- serpens, Wint., 47

- tenue, Ehr., 43,48

- Undula, Ehr., 42, 49, 94

- litorale, Warm., 49 violaceum, Warm., 52
Spirillum volutans, $E h r$., 50 robustum, Warm., 5I

Spirobacteria, 70, 106

Spirochæta, 43

- Cohnii, Wint., 44 gigantea, Warm., 45

- Obermeieri, Cohn, 43

- plicatilis, Ehr., 43

Spirochate

- denticola, Arn., 44

- dentium, Mill., 44

Spiromonas, 45

Cohnii, Warm., 46 volubilis, Perty, 45

Spirulina, 43, 94 alba, $\operatorname{Van} T ., 94$

- plicatilis, Cohn, 43

Splenic fever, 3I, I06

Spores, germination of, $3,17,28$

reproduction by, $3,57,74$

Sporonema gracile, Perty, 90

Staining fluids, 103

Starch, fermentation of, 10

- in fungi, 29, 50

Streptococcus, 70

Streptothrix, 40

- Försteri, Cohn, $4 \mathrm{I}$

Symphyothrix nivea, Brüg., 38

Syphilis, 13, 91, 106

\section{$\mathrm{T}$}

Teeth, decay of, $35,44,47,94$, 106

Thrush, 66

Torula, 32, 67, 73

cerevisia, Turp., 58

Tuberculosis, 32 , 106

Typhoid, I06

Typhus, I3, 105

\section{U}

Unit of measurement, 7 , IOI

Urine, 9, 2I, 9 I

Ustilagineæ, 80 


\section{V}

Variola, 11, 105

Vibrio, 46, 69

- cyanogenus, Fuchs, 26

- Lineola, Mïll., 24 prolifer, Ehr., 49 Rugula, Müll., 47 serpens, Müll., 47

Spirillum, Müll., 50
- subtilis, Ehr., 27

- syncyanus, Ehr., 26 synxanthus, Ehr., 25 tremulans, Ehr., 24

Undula, Müll., 49 xanthogenus, Fuchs, 25

Vibrion butyrique, 29

Vinegar, formation of, 65, 85, 106

Volvox punctum, Müll., 99
W.

Woolsorters' disease, 31

Y

Yeast, 59, 60

Yeast Fungi (see Saccharomycetes)

Yellow fever, 95

Yellow milk, 25

Z

Zoogalactina imetropha, Sette, 7

Zoogloea, 3

Zooglea Termo, Cohn, 23

Zymogenous species, 5 



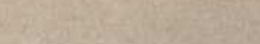

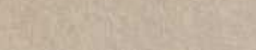

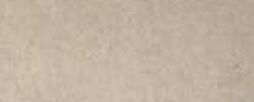





\section{UNIVERSITY OF CALIFORNIA LIBRARY}

\section{Los Angeles}

This book is DUE on the last date stamped below. RECD LD-URL

IIR APR 26'T2 IAPR 15197?

AEC'D LD-URL ORL MAY 16.73 MAY 171982 RECD LD-URE

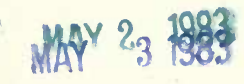


UC SOUTHERN REGIONAL LIBRARY FACILITY

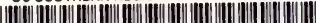
AA $000777186 \quad 8$ 
